\title{
Fluid channeling along thrust zones: the Lagonegro case history, southern Apennines, Italy
}

\author{
T. GABELLONE ${ }^{1}, M \cdot$ GASPARRINI $^{2}, A \cdot$ IANNACE $^{1}, C \cdot$ INVERNIZZI $^{3}, S \cdot$ MAZZOLI $^{1}$ AND \\ M. D’ANTONIO ${ }^{1,4}$ \\ ${ }^{1}$ Dipartimento di Scienze della Terra, dell'Ambiente e delle Risorse, Università di Napoli Federico II, Napoli, Italy; \\ ${ }^{2}$ IFP Energies nouvelles, Rueil-Malmaison, France; ${ }^{3}$ Scuola di Scienze e Tecnologie, Università di Camerino, Camerino (MC), \\ Italy; ${ }^{4}$ Istituto Nazionale di Geofisica e Vulcanologia, sezione di Napoli Osservatorio Vesuviano, Italy
}

\begin{abstract}
A regional study on late burial, syntectonic dolomites and syntectonic calcite and quartz veins occurring in the hemipelagic Triassic-Jurassic succession of the Lagonegro Basin (southern Apennines) was carried out by integrating fieldwork with structural, fluid inclusion, and geochemical investigations on both surface and subsurface samples. The main goal was to characterize the different parent fluids, channeled along a major, out of sequence thrust zone. We also investigated calcite veins from the deeper tectonic mélange zone. The results point out that the fluids at peak burial conditions, during the first deformation stage, were characterized by temperatures of $120-140^{\circ} \mathrm{C}$ and salinities averaging $2 \mathrm{wt} \% \mathrm{NaCl}$ eq. Fluids channeled along the late, out of sequence thrust zone and responsible for partial dolomitization of the succession had lower temperatures $\left(\mathrm{Th}=95 \pm 10^{\circ} \mathrm{C}\right.$ ) and salinities in the range of slightly modified to normal marine seawater (mean at $3.7 \mathrm{wt} \% \mathrm{NaCl}$ eq). Similar low salinities are encountered in late dolomites from other fold-and-thrust belts of Italy. The most probable source for the fluids channeled along the investigated out of sequence thrust zone is represented by Miocene marine pore waters expelled from the tectonic mélange zone. A comparison of the Lagonegro dolomites with similar late stages carbonates formed in other fold-and-thrust belts suggests that fluid salinities appear to be controlled by the different lithologies of the fold-and-thrust belts décollement surfaces.
\end{abstract}

Key words: décollement, dolomitization, fluid inclusions, low salinity

Received 29 July 2012; accepted 23 January 2013

Corresponding author: Tatyana Gabellone, School of Earth Sciences, University of Bristol, Wills Memorial Building, Queen's Road, Bristol, BS8 1RJ, UK.

Email: tatyana.gabellone@bristol.ac.uk. Tel: +44 117954 5415. Fax: +44 1179253385.

Geofluids (2013) 13, 140-158

\section{INTRODUCTION}

Most late (burial to hydrothermal), high-temperature dolomites from many different localities of the Earth are considered to be precipitated from brines with salinities two to nine times higher than modern seawater (Davies \& Smith 2006 and references therein; Gasparrini et al. 2006). However few examples of low-salinity dolomitizing fluids expelled during fold-and-thrust belts (FTBs) imbrication are known, especially in Italy (Dewever et al. 2010; Ronchi et al. 2010). This kind of dolomite has been traditionally described in association with ore deposits, but it has more recently attracted the attention of exploration companies, as it also plays a role as hydrocarbon reservoirs.

Late dolomites are commonly originated in sedimentary basins from high-salinity brines, which may be genetically related to evaporites in three ways: (i) dissolution of evaporite minerals (generally halite); (ii) interstitial fluids in evaporites which are expelled from their source rock during compaction; (iii) incongruent alteration of hydrous evaporite minerals (carnallite; Carpenter 1978). Other mechanisms generating saline groundwater are infiltration of subaerially evaporated seawater or nonmarine fluids and water-rock reactions during burial (Hardie 1990), that is, interactions with evaporites or clay mineral transformations.

In the hemipelagic succession of the Lagonegro Basin (southern Apennines, Italy), zebra-like saddle dolomites were recognized in a preliminary pilot study by Iannace et al. (2012) in few outcrops. These dolomites occur within the Upper Triassic cherty limestones of the Calcari con selce (CCS) Formation (Fm) and were interpreted as burial dolomites, formed through the expulsion of over- 
pressured, warm and low saline fluids (near seawater values). It is suggested that this occurred during a second phase of regional thrusting $(5.5-2.5 \mathrm{Ma})$, coinciding with the beginning of exhumation and NNE-directed shortening. The salinity detected in the Lagonegro dolomites is quite low compared with that characterizing other similar high-temperature dolomites formed by tectonically driven fluid expulsion (Montañez 1994; Qing \& Mountjoy 1994; Hitzman et al. 1998). This salinity may result from slight modification of seawater or dilution of saline formation waters (Iannace et al. 2012), but distinguishing which scenario is most likely, remains problematic.

A multidisciplinary study on the Lagonegro zebra-like dolomites was carried out to better characterize, at a regional scale, the different fluid circulation episodes along the thrust zones locally responsible for dolomitization. Fluid inclusions (FIs) and geochemical analyses were performed both on surface and on subsurface dolomite specimens sampled from new outcrops and one well. Through a geochemical and microthermometric study, we also investigated calcite and quartz veins occurring in different formations of the Lagonegro succession and in the tectonic mélange units (décollement level). These diagenetic products are associated with the two different compressional phases of the southern Apennines deformation history (Miocene buckling and Pliocene thrusting).

Temperature and composition of these veins' parent fluids were compared with those of the dolomitizing fluids, to better understand the fluid evolution scenario along the main thrust zone.

\section{GEOLOGICAL SETTING}

The Lagonegro Basin succession, together with the Apenninic platform successions, is now imbricated in the southern Apennines chain. This latter is a NE-directed FTB, formed by progressive collision between the Afro-Adriatic and the Eurasian plates during the Neogene (e.g., Dewey et al. 1989; Mazzoli \& Helman 1994; Ciarcia et al. 2012; Turco et al. 2012 and references therein), with the Bradanic foredeep representing the main depozone of the Pliocene-Quaternary foreland basin system and the Apulian promontory representing the orogenic foreland (Fig. 1). The classical restoration of the pre-orogenic (Triassic to Paleogene) paleogeography of the southern Apennines shows that the African (Apulian) passive margin was characterized by the Meso-Cenozoic pelagic Lagonegro Basin, located between two coeval carbonate platforms: the Apenninic and Apulian platforms.

According to recent studies (e.g., Mazzoli et al. 2008, 2012 and references therein), the Apennine chain consists of two main parts: (i) the Apennine accretionary wedge and (ii) the buried Apulian platform inversion belt (APIB). The former, made up of sedimentary units detached from their original substratum, includes carbonate platform/ slope and pelagic basin successions, stratigraphically covered by Neogene foredeep and wedge-top sedimentary basins. The structure at shallow levels is dominated by low-angle tectonic contacts separating carbonate platform/ slope successions of the so-called Apenninic platform, in the hanging wall, from pelagic (Lagonegro) basin succes-

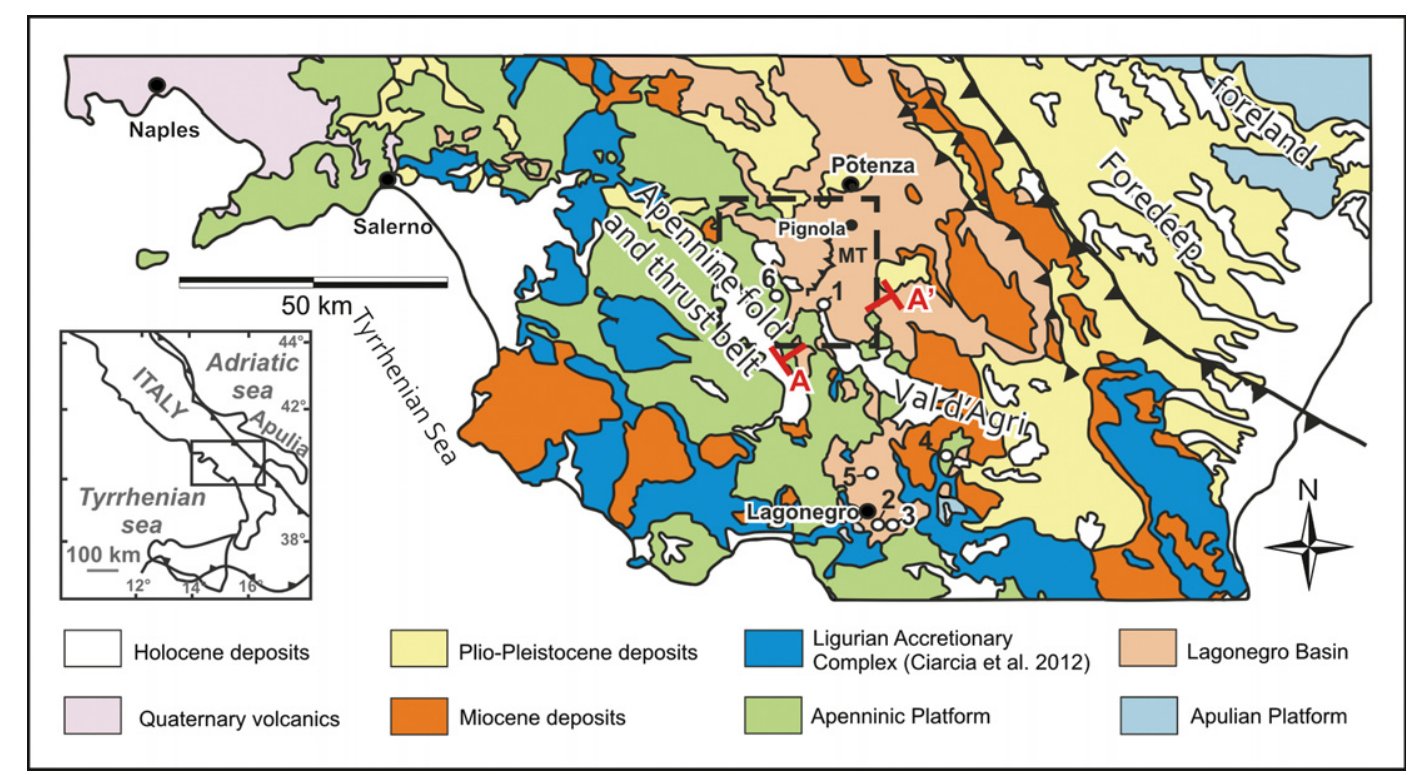

Fig. 1. Geological sketch map of the southern Apennines (modified after Mazzoli et al. 2000). Dolomites were sampled from the Monte Gargaruso well (locality 6) and from outcrops in the area enclosed in the frame with dashed line (see Fig. 4 for more details). Sampling outcrops for calcite and quartz veins are as follows: 1: Mount Cugnone; 2: Masseria Milordo; 3: Varcovalle; 4: Monte Alpi; 5: Tempa di Roccarossa. MT is the Marsico Nuovo Thrust, which is a major thrust fault occurring within the Lagonegro Basin rocks. 
sions in the footwall. The submerged accretionary complex hosted deepwater wedge-top basins whose age reaches the lower Messinian and younger shallow water or continental Plio-Quaternary deposits. Surface geology coupled with abundant subsurface data from the oil industry point out that the Apennine accretionary wedge presently forms an allochthon overlying foreland carbonate platform strata (Apulian platform) continuous with those exposed in the Apulian promontory to the NE (e.g., Mostardini \& Merlini 1986; Casero et al. 1991; Shiner et al. 2004). Buttressing of the accretionary wedge against the western margin of the Apulian platform, wedge uplift and its final emplacement on top of the Apulian platform carbonates are marked by vigorous exhumation recorded by apatite fission track data (cooling ages clustering around 5.5 Ma; Corrado et al. 2005; Mazzoli et al. 2008). This is consistent with a generalized Messinian emersion of the thrust belt (Ascione \& Cinque 1999). The major detachment presently separating the allochthon from the buried Apulian platform carbonates is marked by a tectonic mélange zone penetrated by numerous oil wells and described in detail in Mazzoli et al. (2001a). Beneath the tectonic mélange zone, a variable thickness of Messinian evaporites and, further east, progressively younger Pliocene shales and arenites (refer to the cross-section in Fig. 2) occur on top of the Mesozoic-Tertiary shallow-water carbonates. This tectonically buried portion of the Apulian platform was involved in the final shortening phases, giving rise to the subsurface APIB. This consists of reverse fault-related, open, long-wavelength folds that form the hydrocarbon traps for the significant oil discoveries in southern Italy (Shiner et al. 2004). Thin-skinned thrusting and associated large amounts of horizontal shortening have been proposed for the subsurface Apulian platform carbonates in both the central (e.g., Patacca et al. 2008; Di Luzio et al. 2009) and the southern Apennines (Sciamanna et al. 2004; Scrocca et al. 2005, 2007; Patacca \& Scandone 2007). However, recent geophysical studies have provided evidence that deep-seated reverse faulting involves the basement (Speranza \& Chiappini 2002; Improta \& Corciulo 2006; Steckler et al. 2008). Interpretation of highquality seismic profiles, cross-section balancing, and restoration of the buried Apulian platform carbonates favor an inversion tectonics model involving reactivation of preexisting (Permo-Triassic) basement normal faults (Shiner et al. 2004). The related deformation is characterized by limited horizontal displacements. Therefore, a switch from thinskinned thrusting to thick-skinned inversion appears to have occurred in the southern Apennines as the Apulian platform carbonates, and the underlying thick continental lithosphere was deformed (Mazzoli et al. 2000; Butler et al. 2004).

Crustal shortening ceased in the early part of the Middle Pleistocene at about $0.7 \mathrm{Ma}$ (e.g., Patacca \& Scandone 2001). A new tectonic regime was established in the chain and adjacent foothills (e.g., Cello et al. 1982; Cinque et al. 1993; Hippolyte et al. 1994; Montone et al. 1999), characterized by a NE-SW oriented maximum extension and by dominantly extensional faults that postdate and dissect the thrust belt (e.g., Cello et al. 1982, 2001; Butler et al. 2004). Such faults, locally bounding late Quaternary continental basins, also control active tectonics and seismogenesis in the southern Apennines (e.g., Caiazzo et al. 2006; Ascione et al. 2007; Macchiavelli et al. 2012). Termination of crustal shortening was followed by a final uplift also involving the foredeep. Uplift affecting the eastern portion of the chain since the early Middle Pleistocene is estimated in about $600-700 \mathrm{~m}$. This is based on the elevation of the

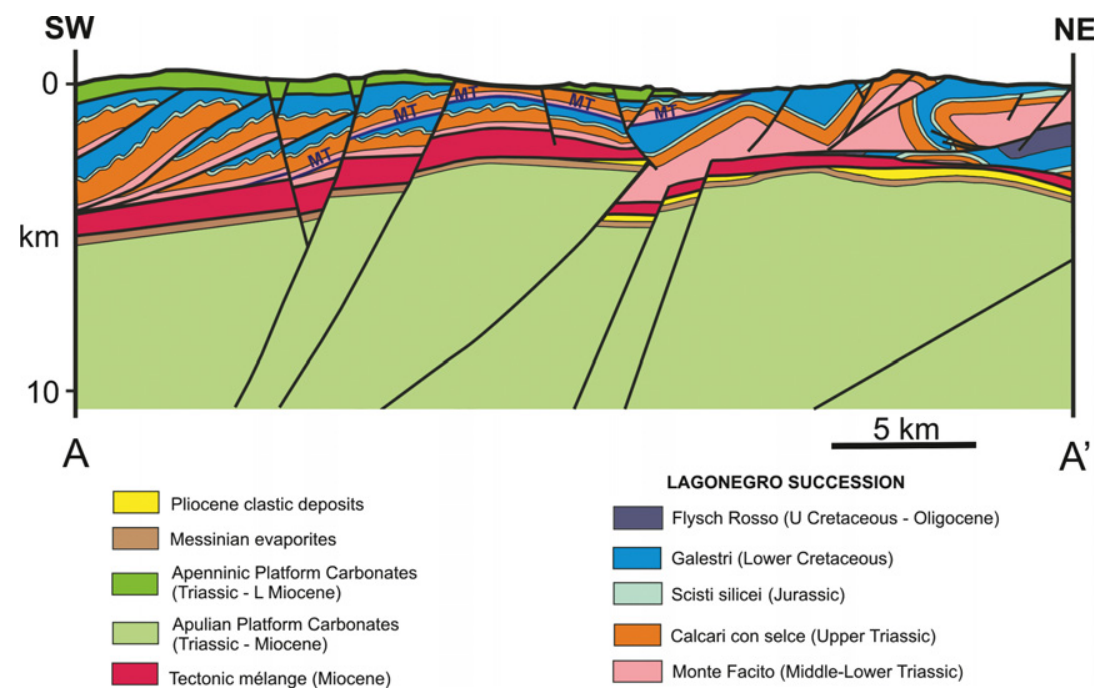

Fig. 2. Cross-section ( $A-A^{\prime}$ in Fig. 1) displaying the Lagonegro units and the underlying units. MT represents the Marsico Nuovo Thrust. 
uppermost depositional surfaces of the basin fill and on the elevation of marine terraces in the Ionian coastal belt (Cinque et al. 1993; Amato 2000).

\section{STRATIGRAPHY AND STRUCTURE OF THE LAGONEGRO BASIN UNITS}

The Lagonegro hemipelagic succession (Fig. 3) starts with the Monte Facito (MF) Formation (Fm), consisting of Lower-Middle Triassic shallow-water terrigenous and carbonates deposits (Scandone 1967; Ciarapica et al. 1990). The thickness of this Formation is about $200 \mathrm{~m}$. The overlying Upper Triassic Calcari con selce (CCS) Fm is made up of deepwater micritic limestones, often replaced by dolomites, containing thin-shelled bivalves and radiolarians, with beds and chert nodules. Locally, they consist of calcarenites, calcirudites, and marls. The thickness of the CCS Fm is variable, and in outcrops, it reaches a maximum of about $500 \mathrm{~m}$. This Formation gradually passes toward the

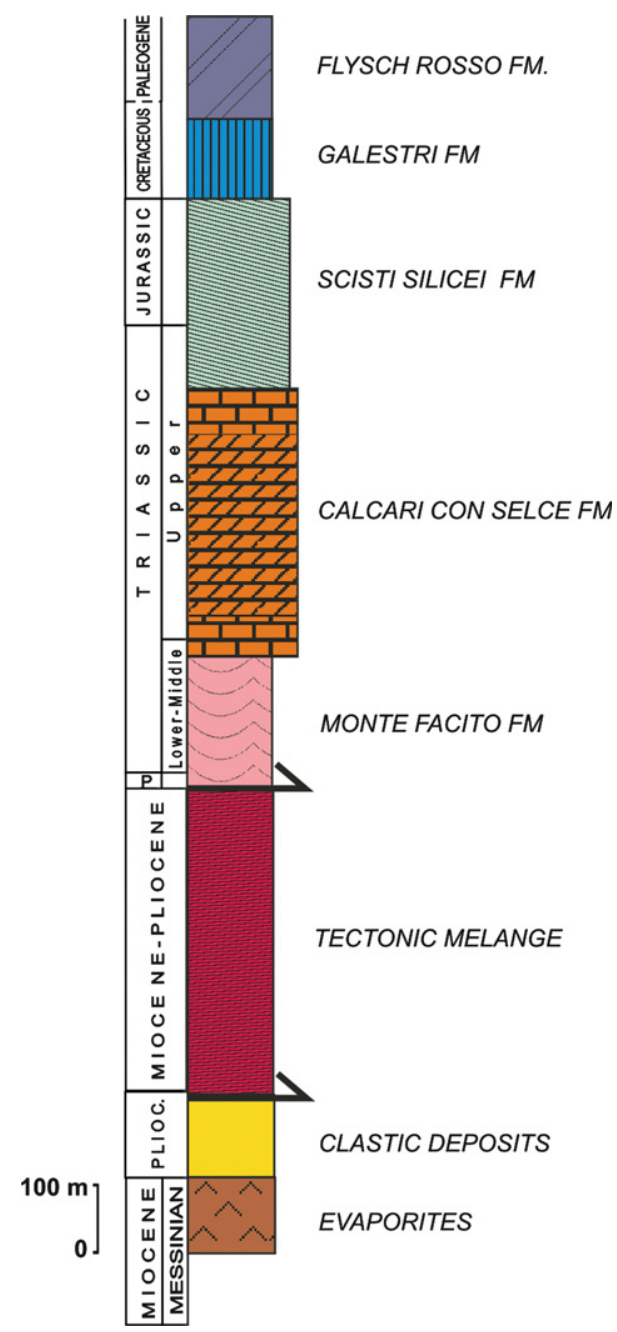

Fig. 3. Simplified stratigraphic column of the Lagonegro succession and the tectonically underlying units. overlying Scisti Silicei (SS) Fm, whose maximum thickness is $250 \mathrm{~m}$, and which consists of Jurassic shales, radiolarites and, in some areas, resedimented interbeds of silicified carbonates. On the top, the Galestri Fm (Lower Cretaceous) and the so-called Flysch Rosso (Upper Cretaceous-Oligocene) complete the Lagonegro succession. The former is made up of turbiditic siliceous marls and shales, while the latter consists of calcareous clastic sediments interbedded with reddish marls and shales.

The Lagonegro units in the study area (Figs 1 and 4) are characterized by different but clearly correlatable Mesozoic successions consisting mainly of deepwater cherty limestones and radiolarian cherts. Detailed geological mapping, fieldwork, and subsurface data from hydrocarbon exploration wells, together with the revision of previous works (Scandone 1967, 1972), allowed us to recognize four distinct Lagonegro units on the basis of lithostratigraphic characteristics, such as depositional facies and overall thickness. With respect to the present-day structure of the FTB, one of these units crops out in the hanging wall to the major thrust fault occurring within the Lagonegro Basin rocks (Marsico Nuovo Thrust; refer to cross-section of Figs 2 and 4). The other three units are exposed in the footwall to the Marsico Nuovo Thrust. The age of the Lagonegro Basin rocks in the footwall to the Marsico Nuovo Thrust is highly variable, and not simply younging toward the thrusting direction (i.e., northeast). Furthermore, the thrust surface truncates preexisting folds within the underlying Lagonegro successions. Along this major tectonic contact, younger-on-older thrust relationships are also locally observed. Kinematic indicators (including S-C tectonites, shear bands, rotated clasts, and asymmetric pressure shadows around rigid objects) from the several meters thick shear zone associated with the Marsico Nuovo Thrust in the Lagonegro village northern area (Tempa di Roccarossa, locality 5 in Fig. 1) indicate a top-to-the-NNE sense of shear (Mazzoli 1992). Based on the stratigraphic evidence (i.e., age of the youngest deposits occurring at its footwall and of the first sediments sealing the tectonic contact), the activity of this out of sequence thrust may be constrained between the late Messinian and the Late Pliocene (Ascione et al. 2012).

The structure of the Lagonegro units exposed in the footwall to the Marsico Nuovo Thrust - and truncated by such an out of sequence structure - developed mainly during the Middle to Late Miocene (e.g., Mazzoli 1992; Mazzoli et al. 2001a). In the northern sector of the study area (frame with dashed line in Figs 1 and 4), they include a series of major, roughly north-south-trending, faulted antiforms. Some of these major structures are bounded on their eastern and western sides by (either emergent or blind) thrusts and backthrusts, respectively, and show a double vergence of associated fold structures. A balanced cross-section by Mazzoli et al. (2001a) clearly shows that 


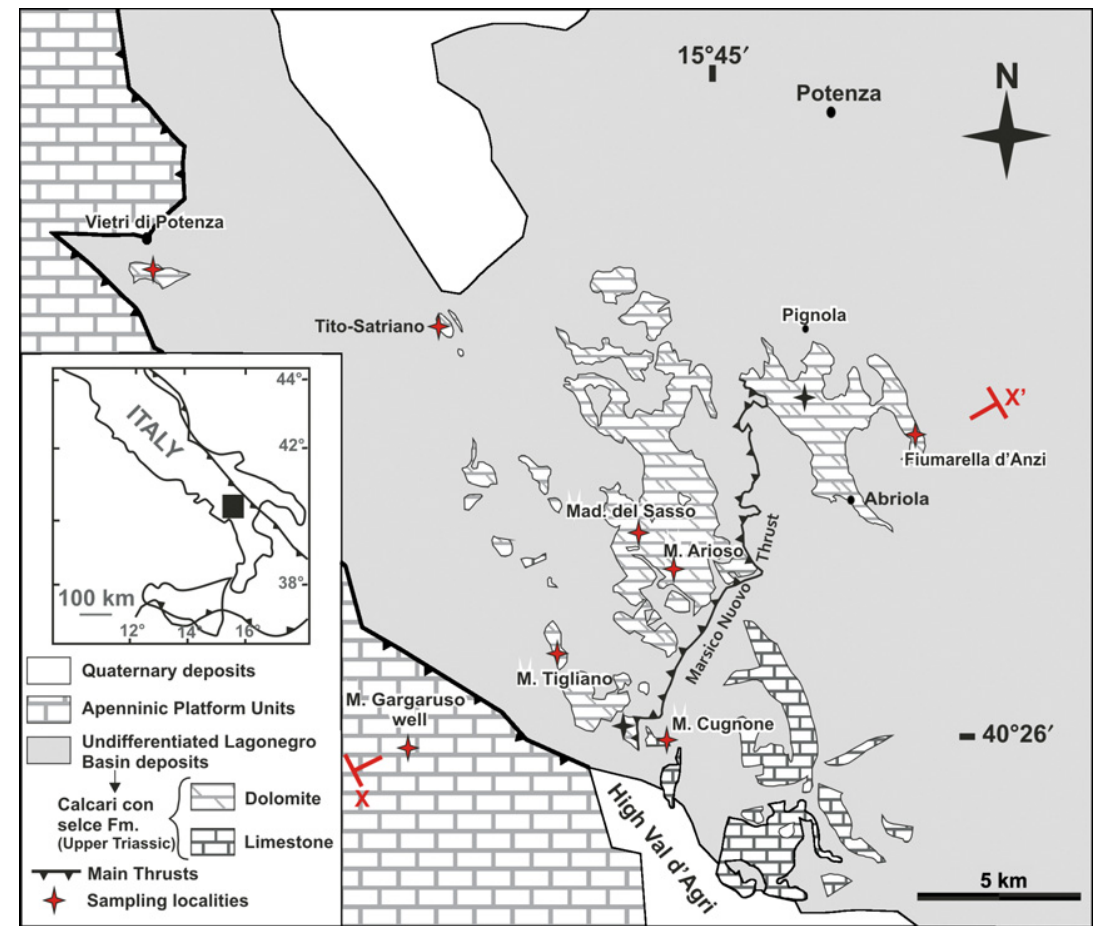

Fig. 4. Simplified geological map of the study area (for the dolomites) displaying the location of outcrops and well (red stars). This area is that enclosed in the frame with dashed line of Fig. 1. Samples collected along the transect XX' constitute the Group 1 of dolomites. Group 2 consists of two samples from Vietri di Potenza and Tito-Satriano. The outcrops previously studied by lannace et al. (2012) are here represented by black stars.

wavelength and amplitude are larger for those folds involving the thicker succession of the so-called San Nicola unit and much smaller for those involving the thinner succession of the so-called Caldarosa unit (both belonging to the footwall block to the Marsico Nuovo Thrust), this being consistent with folding produced by buckling processes. In both instances, fold geometry also indicates that these major structures are detached along the MF Fm at the base of the succession. This is also the case for upright to recumbent, mostly E-vergent, first-phase folds developed in the southern sector of the study area (i.e., Lagonegro village area; Mazzoli 1992).

\section{METHODS AND SAMPLING}

Syntectonic calcite and quartz veins related to the first compressional phase (Miocene buckling) of the southern Apennines FTB formation were sampled in the Upper Triassic undolomitized cherty limestones of the CCS Fm at Mount Cugnone (locality 1 in Figs 1 and 4). These same vein types were also sampled from the Jurassic radiolarian cherts of the SS Fm in three different localities: Mount Cugnone, Masseria Milordo, and Varcovalle (respectively, localities 1, 2, 3 in Fig. 1). Calcite and quartz veins related to the second deformation stage, reembricating the Lagonegro succession (Pliocene out of sequence thrusting), were instead sampled in the LowerMiddle Triassic siliciclastics rocks of the MF Fm at Tempa di Roccarossa (locality 5 in Fig. 1). Calcite veins relative to the same second compressional event were also sampled in Miocene pelitic rocks of the tectonic mélange unit underlying the Lagonegro units and exposed at Monte Alpi (locality 4 in Fig. 1; Corrado et al. 2002; Mazzoli et al. 2006).

Dolomites are thought to have formed during the second compressional phase of the southern Apennine FTB formation (Iannace et al. 2012). To investigate potential temperature and salinity variations of dolomitizing fluids in the direction of transport within the Apennine thrust belt, samples of dolomite were taken from the CCS Fm along a W-SW to E-NE transect (XX' in Fig. 4) in the Lagonegro area (Group 1). These samples included cuttings from the Monte Gargaruso well (locality 6 in Figs 1 and 4) and those taken from outcrops. Further dolomite samples (Group 2) were collected in a northwest area compared with the transect, that is, at Vietri di Potenza and TitoSatriano (Fig. 4).

Thin sections $(30-35 \mu \mathrm{m})$ of all samples were prepared for conventional and cathodoluminescence (CL) microscopy. Petrographic observations were accomplished with a Leica DM-EP microscope, while a CCL $8200 \mathrm{mk} 3$ was used for cold CL analyses. 
Geochemical analyses for most carbonate (both calcite and void-filling dolomite) powder samples were performed at the Isotopen-labor of the Institut für Geologie, Mineralogie und Geophysik of the Ruhr University (Bochum, Germany). For the oxygen and carbon stable isotopes, analyses about $0.5 \mathrm{mg}$ of powder were heated for $18 \mathrm{~h}$ at $105^{\circ} \mathrm{C}$. The isotopic value was measured through a mass spectrometer (Finnigan Delta $S$ ). The precision $(1 \delta)$ was $\pm 0.09 \%$ for the carbon and $\pm 0.13 \%$ for the oxygen. All values are reported in per mill $(\%)$ relative to the V-PBD international standard (Vienna Pee Dee Belemnite, South Carolina, USA). The dolomite acid correction factor from Rosenbaum \& Sheppard (1986) was applied.

Strontium isotopic compositions were determined by thermal ionization mass spectrometry partly at Bochum, using a Finnigan MAT 262 multicollector mass spectrometer and partly at Istituto Nazionale di Geofisica e Vulcanologia - Sezione di Napoli Osservatorio Vesuviano, using a ThermoFinnigan Triton TI multicollector mass spectrometer, after conventional ion-exchange procedures for Sr separation from the matrix. Measured ${ }^{87} \mathrm{Sr} /{ }^{86} \mathrm{Sr}$ ratios were normalized for within-run isotopic fractionation to ${ }^{86} \mathrm{Sr} /{ }^{88} \mathrm{Sr}=0.1194$. Sr blanks were on the order of $0.3 \mathrm{ng}$ during the period of chemistry processing. $2 \sigma_{\text {mean }}$, that is, the standard error, is better than \pm 0.000020 for measurements made at the Bochum laboratory and \pm 0.000010 for measurements made at the Naples laboratory. The measured $\mathrm{Sr}$ isotope ratios are considered to be free of interlaboratory bias because, during the collection of isotopic data, replicate analyses of NIST SRM $987\left(\mathrm{SrCO}_{3}\right)$ standard have been performed at both laboratories to check for external reproducibility, that is, the mean measured value of ${ }^{87} \mathrm{Sr} /{ }^{86} \mathrm{Sr}$ for NIST SRM $987(2 \sigma$, where $\sigma$ is the standard deviation of the standard results). The latter was $0.710240 \pm 0.000035(2 \sigma, N=215)$ at the Bochum laboratory and $0.71022 \pm 0.00002(2 \sigma, N=54)$ at the Naples laboratory. All Sr isotope ratios have been normalized to the recommended value of NIST SRM 987 standard $\left({ }^{87} \mathrm{Sr} /{ }^{86} \mathrm{Sr}=0.71025\right)$.

ICP-AES (inductively coupled plasma - atomic emission spectrometry) measurements were performed to determine minor elements ( $\mathrm{Sr}, \mathrm{Fe}$, and $\mathrm{Mn}$ ) concentration in the calcite samples (i.e. Bussolotto et al. 2007). Approximately $1 \mathrm{mg}$ of powder was dissolved in $1 \mathrm{ml}$ of $\mathrm{HCl} \mathrm{l} \mathrm{Mol}$, diluted in $4 \mathrm{ml}$ of $\mathrm{H}_{2} \mathrm{O}$, and analyzed with an atomic spectrometer (ICP-AES). Measurement of concentration was achieved with an accuracy of $< \pm 2 \%$.

Two-phase FIs within calcite and quartz veins from limestone and radiolarian chert samples were investigated by microthermometry with a USGS heating-freezing stage. Petrographic analyses were performed on 11 double-polished thick sections $(150-200 \mu \mathrm{m})$; nine of them provided reliable results showing well-preserved two-phase primary fluid inclusions both in quartz and in calcite crys- tals. Distinct fluid inclusion assemblages (FIAs) were measured from crystals belonging to the inner and outer part of syntaxial veins. Microthermometry was also performed on two-phase FIs within saddle dolomite cements from 9 double-polished thick sections $(100-120 \mu \mathrm{m})$ with a Linkam MDS 600 heating-freezing stage. The Linksys 32 software enabled all the operations for FI petrography and microthermometry. Different FIAs were established based on the inclusions location within the crystals, for example, crystal core, internal and external growth zones, patches, etc.

Both microthermometry stages were calibrated using synthetic FIs at $-56.6\left(\mathrm{CO}_{2}\right), 0.1$ and $374^{\circ} \mathrm{C}\left(\mathrm{H}_{2} \mathrm{O}\right)$, $-20.9^{\circ} \mathrm{C}\left(\mathrm{NaCl}-\mathrm{H}_{2} \mathrm{O}\right)$. The accuracy of both dataset was $\pm 1^{\circ} \mathrm{C}$ for heating runs and $\pm 0.1^{\circ} \mathrm{C}$ for cooling runs. Homogenizations (always to liquid phase) were repeated twice when the temperatures diverged from those acquired in the same FIA. The inclusion data were discarded from the database if the second homogenization measurement exceeded the first. When salinity and Th from different FIAs within the same sample were comparable, a cumulative histogram for each sample was produced. Similarly, data from different samples were cumulated in the same histogram when they showed consistent results.

Salinities were calculated from final ice-melting temperatures using the equation of Bodnar (1993) in the $\mathrm{H}_{2} \mathrm{O}$ $\mathrm{NaCl}$ system and are reported as equivalent weight percent $\mathrm{NaCl}$ (wt\% $\mathrm{NaCl}$ eq). Composition and density of FIs were calculated using the computer package FLUIDS (Bakker 2003, 2009), which includes the programs BULK and LONER32. Fluid density of single FIs was calculated through the application BULK, which uses the equation of state for aqueous systems of Krumgalz et al. (1996) and the volume fractions of the liquid phase of FIs at room temperature. The program LONER32 was used to calculate the isochore slope for FIs of each sample according to the model of Bodnar \& Vityk (1994). The input data were the mean value of the salinity and the homogenization temperature (minimum, maximum, and mode values) of the FIs.

\section{MACROSCOPIC AND PETROGRAPHIC OBSERVATIONS}

The analyzed samples are from intensely deformed, calcite veins that are flattened along a west-dipping, sigmoidal foliation. This foliation constitutes $S$ surfaces within welldeveloped S-C-C' tectonites indicating top-to-the-E sense of shear. The tectonic mélange zone exposed at Monte Alpi consists of a shear zone, which accommodated the late (i.e., post-Messinian; Mazzoli et al. 2006), E-directed emplacement of the allochthonous units (Lagonegro and overlying nappes) on top of the Apulian platform carbonates in this sector of the southern Apennines. 
Calcite veins in the CCS Fm developed as en echelon arrays in the micritic limestones (Fig. 5A). They are mainly arranged in conjugate sets and show evidence of shear displacement with extensional offset (Mazzoli \& Di Bucci 2003; Mazzoli et al. 2004). The veins consist of a thick central portion and tapered tails, and they are usually planar. In thin section, veins from the CCS consist of sparry, euhedral calcite crystals with sweeping extinction, and various degree of twinning (Fig. 5B). Grain overgrowth coronas were also observed. Isoriented calcite fibers, where present, indicate mode I opening of the veins (Lawn \& Wilshaw 1975).

Quartz veins in the SS Fm are either perpendicular or parallel to foliation, with syntaxial growth (Fig. 5C). Quartz crystals show straight margins and localized sweeping extinction.

Calcite extension veins in the MF Fm are mainly related to a low-angle shear zone. They are both parallel and perpendicular to the transport direction. Calcite crystals are generally euhedral, with diffuse twinning and sometimes with penetrative boundaries. Cloudy crystals are also common.

The studied dolomites of the CCS Fm are mainly coarse crystalline and fabric destructive, displaying zebra-structures, mostly bedding-parallel, consisting of alternating bands of a light gray replacive dolomite, and a white sparry void-filling dolomite (Fig. 6A). In some outcrops, the replacive and the void-filling dolomites form hydrofracturing breccias (Fig. 6B). The dolomitized bodies are always irregular, and in some outcrops, sharp dolomitization fronts were observed.
In thin section, the replacive dolomite presents a bimodal nonplanar-A mosaic of cloudy crystals showing a straight extinction, with size ranges from 20 to $80 \mu \mathrm{m}$ and from 100 to $200 \mu \mathrm{m}$ (Fig. 6C). The void-filling dolomite consists of nonplanar-A crystals, with sweeping extinction, commonly elongated along the growth direction, and size ranging from $800 \mu \mathrm{m}$ up to some $\mathrm{mm}$. The crystal margins are bordered by nonplanar- $\mathrm{C}$ scimitar-like shape crystals showing a zonation, related to the alternation of growth zones with variable FIs content (Fig. 6D). Both replacive and void-filling dolomites display a uniform dull red color under CL. In the cuttings from the Monte Gargaruso well, the dolomites present the same petrographic features of the dolomites described from outcrops.

\section{STABLE ISOTOPE, MINOR ELEMENTS, AND FLUID INCLUSION DATA}

$\mathrm{O}$ and $\mathrm{C}$ stable isotope values were obtained for 6 calcite veins from the Upper Triassic CCS Fm, 3 calcite veins from the Lower-Middle Triassic MF Fm and 4 calcite veins from the Miocene tectonic mélange units. Values of the same stable isotopes were acquired also for 8 void-filling dolomites from both outcrops and a well (Monte Gargaruso) of the Upper Triassic CCS Fm (Table 1). These data results are displayed in the $\delta^{18} \mathrm{O}$ versus $\delta^{13} \mathrm{C}$ cross-plot of Fig. 7. ${ }^{87} \mathrm{Sr} /{ }^{86} \mathrm{Sr}$ ratios were measured on 4 calcite veins from the CCS Fm, on 2 calcite veins from the MF Fm, on 5 calcite veins from the tectonic mélange, and on 2 void-
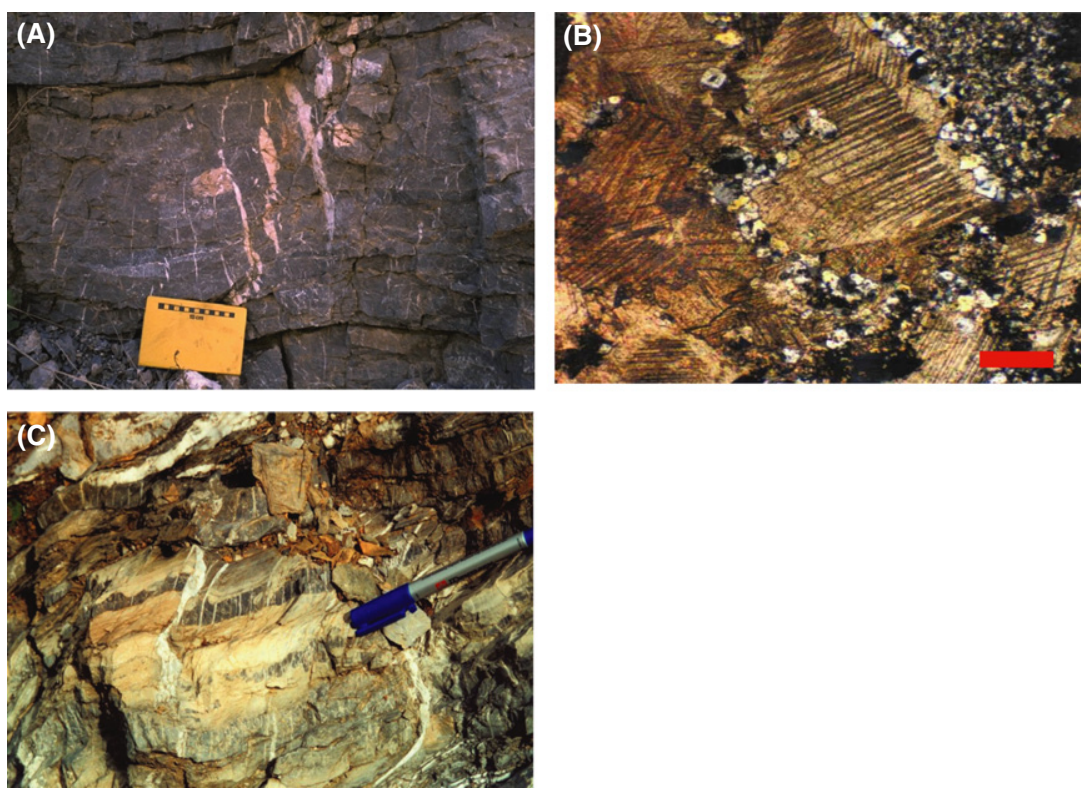

Fig. 5. Macroscopic and petrographic features of the studied syntectonic calcite and quartz veins. (A) En echelon calcite veins array in the cherty limestones of the Calcari con selce Formation (Fm). Scale bar is $15 \mathrm{~cm}$. (B) Photomicrograph (plane-polarized light) of calcite crystals from the Calcari con selce Fm displaying twinning. Scale bar (in red) is $300 \mu \mathrm{m}$. (C) Quartz veins in the radiolarian chert of the Scisti Silicei Fm. 

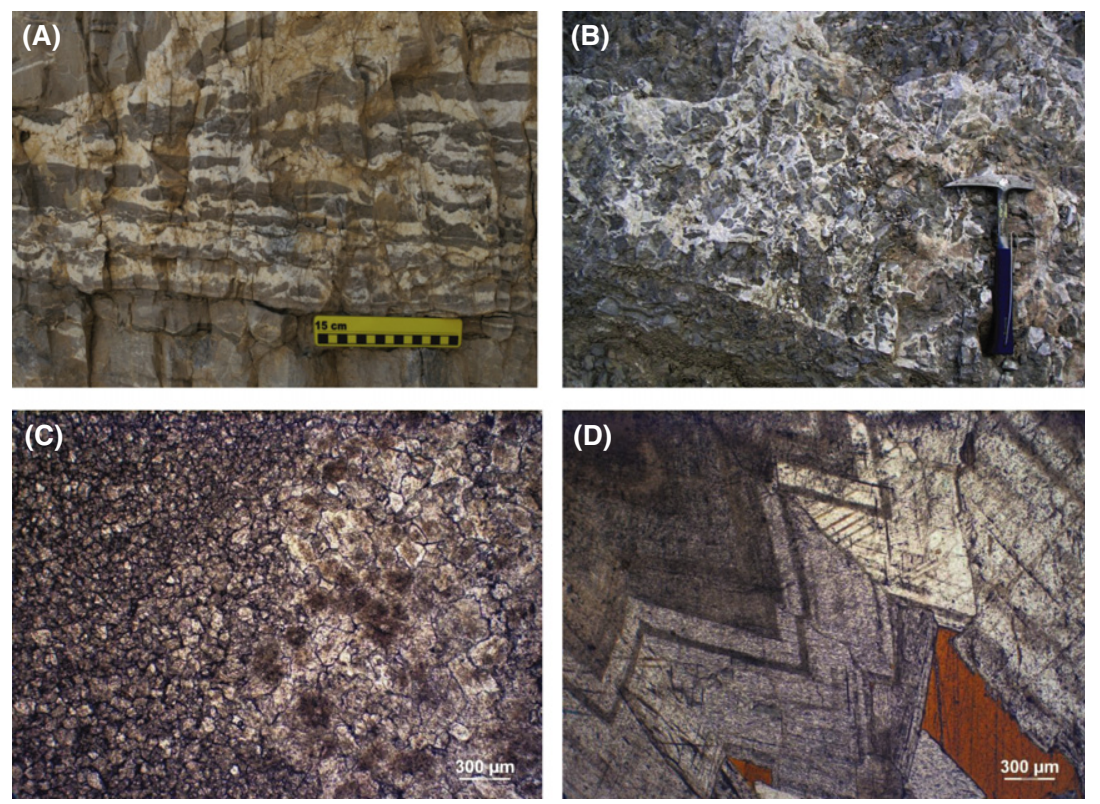

Fig. 6. Macroscopic and petrographic features of the studied dolomites from the Calcari con selce Formation. (A) Zebra-type structure, displaying alternating bands of gray replacive and white void-filling dolomites. (B) Hydrofracturing dolomite breccia. (C) Photomicrograph in plane-polarized light of the replacive dolomites, showing two main crystals size populations: fine $(40-80 \mu \mathrm{m})$ crystals are on the left of the picture, while coarser crystals $(150-200 \mu \mathrm{m})$ are on the right. (D) Photomicrograph in plane-polarized light of the void-filling dolomite, showing non planar-C crystals exhibiting a zoning due to alternation of zones of different fluid inclusions content.

Table 1 Stable isotopes and minor elements data for the studied calcite and dolomite samples.

\begin{tabular}{|c|c|c|c|c|c|c|c|c|c|}
\hline Sample & Locality & $\mathrm{Fm}$ & Mineralogy & $\delta^{18} \mathrm{O}(\mathrm{PDB})$ & $\delta^{13} \mathrm{C}(\mathrm{PDB})$ & ${ }^{87} \mathrm{Sr} /{ }^{86} \mathrm{Sr}$ & $\mathrm{Sr}(\mathrm{ppm})$ & $M n$ (ppm) & $\mathrm{Fe}(\mathrm{ppm})$ \\
\hline A1 & M. Cugnone & $\mathrm{CCS}$ & calcite & -3.50 & 2.50 & - & 558 & 131 & 951 \\
\hline A2 & M. Cugnone & $\mathrm{CCS}$ & calcite & -3.66 & 2.49 & 0.707935 & 1285 & 140 & 675 \\
\hline $\mathrm{A} 1^{\prime}$ & M. Cugnone & $\mathrm{CCS}$ & calcite & -3.59 & 2.49 & 0.708001 & 821 & 117 & 612 \\
\hline SA1-A & M. Cugnone & CCS & calcite & -3.78 & 2.38 & 0.707926 & 867 & 122 & 866 \\
\hline SA1-B & M. Cugnone & CCS & calcite & -3.75 & 2.39 & 0.707906 & 1409 & 160 & 1151 \\
\hline SA3 & M. Cugnone & CCS & calcite & -4.01 & 2.57 & - & 481 & 117 & 645 \\
\hline F1 & Tempa di Roccarossa & MF & calcite & -6.92 & 2.03 & - & 506 & 53 & 403 \\
\hline F2 & Tempa di Roccarossa & MF & calcite & -10.78 & -0.45 & 0.710144 & 3999 & 2560 & 6740 \\
\hline F4 & Tempa di Roccarossa & MF & calcite & -12.02 & 0.34 & 0.710656 & 19700 & 151 & 363 \\
\hline $955 \mathrm{~A}$ & M. Alpi & mel & calcite & -7.89 & -0.27 & 0.709299 & - & - & - \\
\hline $955 \mathrm{~B}$ & M. Alpi & mel & calcite & -7.79 & -0.32 & 0.709196 & - & - & - \\
\hline $955 C$ & M. Alpi & mel & calcite & - & - & 0.709021 & - & - & - \\
\hline 955D & M. Alpi & mel & calcite & -8.32 & 0.17 & 0.709225 & - & - & - \\
\hline $955 \mathrm{E}$ & M. Alpi & mel & calcite & -10.01 & -0.28 & 0.708697 & - & - & - \\
\hline TG40 & Fiumarella d'Anzi & $\mathrm{CCS}$ & dolomite & -5.50 & 2.43 & - & - & - & - \\
\hline TG61 & Madonna del Sasso & CCS & dolomite & -7.33 & 2.33 & 0.708300 & - & - & - \\
\hline TG81 & Vietri di Potenza & CCS & dolomite & -11.82 & 2.59 & 0.708814 & - & - & - \\
\hline TG84 & Tito-Satriano & $\mathrm{CCS}$ & dolomite & -6.44 & 2.51 & - & - & - & - \\
\hline TG89 & M. Arioso & CCS & dolomite & -4.56 & 2.47 & - & - & - & - \\
\hline TG104 & M. Tigliano & $\mathrm{CCS}$ & dolomite & -6.99 & 2.43 & - & - & - & - \\
\hline GA4105 & M. Gargaruso (well) & CCS & dolomite & -5.43 & 2.68 & - & - & - & - \\
\hline GA4145 & M. Gargaruso (well) & CCS & dolomite & -6.95 & 2.62 & - & - & - & - \\
\hline
\end{tabular}

Fm, Formation; CCS, Calcari con selce; MF, Monte Facito; mel, mélange.

filling dolomites from the CCS Fm (Table 1) and are displayed in the frequency histogram of Fig. 8.

Calcite samples of the CCS Fm show limited ranges in $\delta^{18} \mathrm{O}, \delta^{13} \mathrm{C}$, and ${ }^{87} \mathrm{Sr} /{ }^{86} \mathrm{Sr}$, with values of $-3.72 \pm 0.3$, $2.47 \pm 0.1$, and $0.7079 \pm 0.00006$, respectively. These $\delta^{13} \mathrm{C}$ and ${ }^{87} \mathrm{Sr} /{ }^{86} \mathrm{Sr}$ values fall in the isotopic range of Upper Triassic seawater (respectively, $0 /+4$ and $0.7076 /$ 0.7080 as reported by Veizer et al. 1999; Korte et al. 2005; McArthur \& Howarth 2004). They are also in agreement with the $\mathrm{C}$ and $\mathrm{Sr}$ isotope values displayed by 


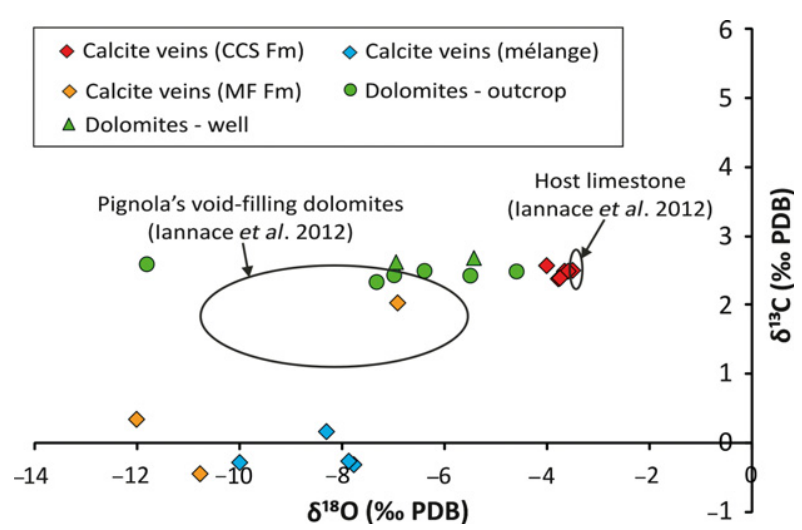

Fig. 7. Covariaton plot between $\delta^{18} \mathrm{O}$ and $\delta^{13} \mathrm{C}$ of the studied calcite veins and void-filling dolomites. Isotopic values of dolomites from Pignola (see Fig. 4 for location) and of the host limestone are reported in the two ellipses (data from lannace et al. 2012).

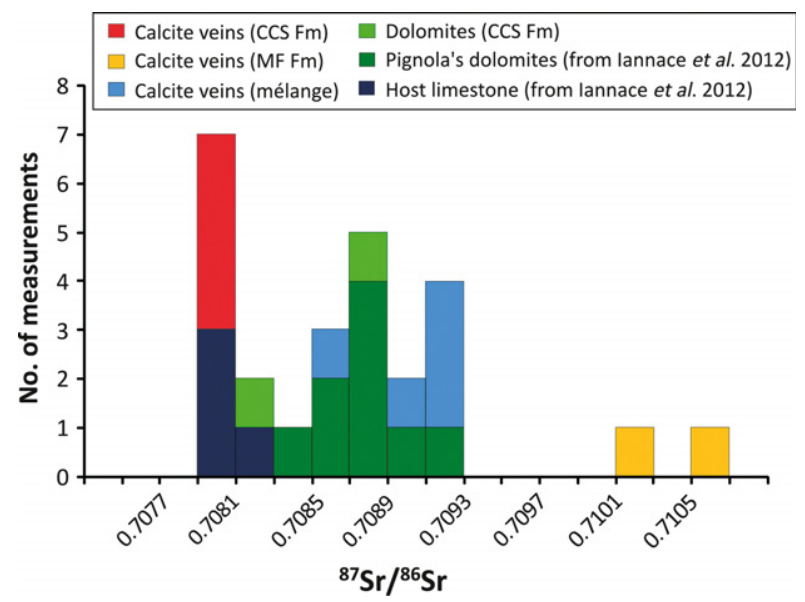

Fig. 8. Histogram showing the frequency distribution of ${ }^{87} \mathrm{Sr} /{ }^{86} \mathrm{Sr}$ ratios in the studied calcite veins and void-filling dolomites. Sr isotope values of the host limestone and of further void-filling dolomites are reported from lannace et al. 2012.

the host limestones (Iannace et al. 2012; Figs 7 and 8), while the $\delta^{18} \mathrm{O}$ is slightly lighter than Upper Triassic seawater (-3.5/0, Veizer et al. 1999), but almost overlaps the oxygen isotopic signature of the host rock (Iannace et al. 2012; Fig. 7).

The calcite veins of the MF Fm present $\delta^{13} \mathrm{C}$ values between -0.45 and 2.03 , with a mean at 0.64 , which overlaps values of the Lower-Middle Triassic seawater $(-2 /+4$, Veizer et al. 1999; Korte et al. 2005). On the other hand, $\delta^{18} \mathrm{O}$ values, ranging between -12.02 and -6.92 (mean at -9.91 ), are very depleted with respect to the Triassic marine signature $(-6.5 /-1$, Veizer et al. 1999; Korte et al. 2005) and are more in line with the oxygen isotope values displayed by the dolomites of the CCS Fm (range of $-11.82 /-4.56$ with mean at -6.88 ).
Sr stable isotopes of the calcite veins from the MF Fm show a mean at 0.7104 , which is highly radiogenic compared with estimated Lower-Middle Triassic ${ }^{87} \mathrm{Sr} /{ }^{86} \mathrm{Sr}$ values $(0.7076 / 0.7083$; McArthur \& Howarth 2004). It is also higher with respect to the $\mathrm{Sr}$ isotopes ratios showed by the dolomites (range of 0.7083 and 0.7088$). \delta^{13} \mathrm{C}$ values of the studied dolomites are between 2.33 and 2.68, and reflect both the Upper Triassic seawater (Veizer et al. 1999; Korte et al. 2005) and the host limestones carbon isotope compositions (Iannace et al. 2012; Fig. 7).

The calcite veins from the Miocene tectonic mélange units have a $\delta^{18} \mathrm{O}$ mean value of -8.50 and a $\delta^{13} \mathrm{C}$ mean value of -0.17 . This latter value conforms to the Miocene seawater carbon isotopes composition $(-0.5 /+2)$, while the $\delta^{18} \mathrm{O}$ is lighter than the Miocene estimated seawater values $(+1.5 /+3$, Zachos et al. 2001), and falls in the same range of the dolomites oxygen isotope values. Sr stable isotopes, obtained for the samples from the tectonic mélange, present values between 0.7087 and 0.7093 (mean of $0.7091)$, which are only slightly radiogenic relative to the Miocene $\mathrm{Sr}$ isotopes signature (McArthur \& Howarth 2004), and almost overlap the dolomites values (Fig. 8).

Six calcite veins from the CCS Fm and 3 calcite veins from the MF Fm were analyzed for minor elements ( $\mathrm{Sr}$, $\mathrm{Mn}$, and Fe) content (Table $\mathrm{l}$ ). Sr content in the CCS Fm samples varies between 481 and 1409 ppm (mean of 904 ppm), while their Fe concentration is between 612 and $1151 \mathrm{ppm}$ (mean of $817 \mathrm{ppm}$ ) and their $\mathrm{Mn}$ between 117 and $160 \mathrm{ppm}$ (mean of $131 \mathrm{ppm}$ ). The calcites from the MF Fm show a very high $\mathrm{Sr}$ concentration with a mean at $8068 \mathrm{ppm}$ (range 506-19 $700 \mathrm{ppm}$ ). Also, the Fe and Mn content is high with range of 363-6740 ppm and 53$2560 \mathrm{ppm}$ and mean at 2502 and 921 ppm, respectively.

Fluid inclusions analyses were performed both on limestone and on dolomite samples. No measurable inclusions were found in the calcite veins of the tectonic mélange. Analysis of the limestones was performed on samples collected from outcrops of CCS, SS, and MF Fms (see Fig. I for location). Quartz and calcite veins related to compressional tectonic events were analyzed. Two-phase (liquid + vapor) FIs, 5-20 $\mu \mathrm{m}$ of length in size, were measured. Homogenization temperatures (Th) show a broad mode between 120 and $140^{\circ} \mathrm{C}$ in samples from CCS and SS Fms (Fig. 9), both in the footwall of the second phase thrust. Fluid salinity is always very low (mean at $2 \mathrm{wt} \% \mathrm{NaCl}$ eq; Fig. 10) according to ice-melting temperatures (Tmi) in the range of $-0.4 /-2^{\circ} \mathrm{C}$ (Fig. 9). Samples from the $\mathrm{MF}$ $\mathrm{Fm}$ belong to extension veins related to shear zones of the second deformation stage that re-embricated the Lagonegro succession. Th shows a mode around $125^{\circ} \mathrm{C}$, and Tmi reveals a slightly higher fluid salinity (Tmi mean $=-2.3^{\circ} \mathrm{C}$, salinity mean $=3.9$ wt $\% \mathrm{NaCl}$ eq; Figs 9 and 10). The high dispersion in Th distribution is due to partial re-equilibration. Indeed, some fluid inclusions showed a higher 

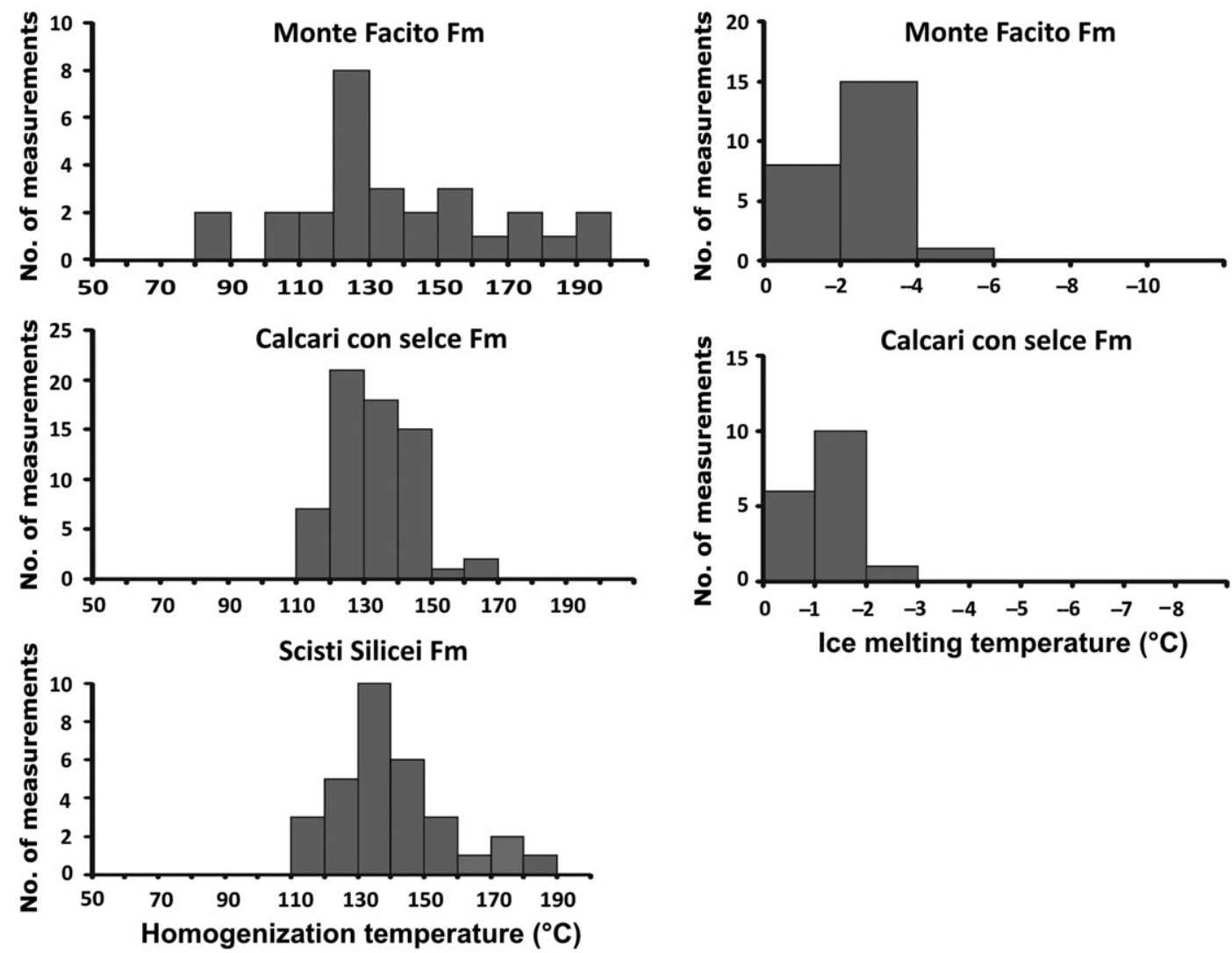

Fig. 9. Histograms showing the frequency distribution of homogenization temperatures (left column) and ice-melting temperatures (right column) values of syntectonic calcite and quartz veins from the different formations (Fms) of the Lagonegro succession.

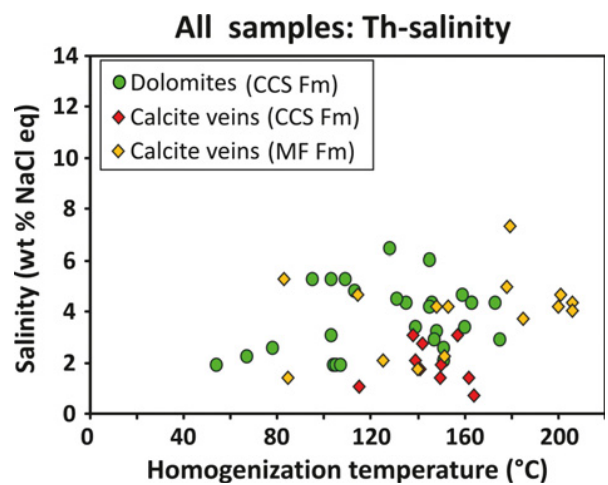

Fig. 10. Homogenization temperature-salinity cross-plot of the studied fluid inclusions from both calcite and dolomite samples. CCS Fm = Calcari con selce Formation; MF Fm: Monte Facito Formation.

vapor\% $(>20 \%)$, and their Th values $\left(>180^{\circ} \mathrm{C}\right)$ may overestimate the mean Th value for MF. Nevertheless, the frequency distribution of Th data is symmetric, and the highest Th values can be considered as a tail referring to reequilibrated FIs.

Regarding the dolomite samples of the CCS Fm, FI microthermometry was performed only on void-filling dolomite crystals, as the replacive dolomite crystals exhibit inclusions too small $(<2 \mu \mathrm{m})$ for analysis. The void-filling dolomite crystals hold biphase liquid-rich inclusions measuring 5$10 \mu \mathrm{m}$ in length. All the samples located along the studied transect (XX' in Fig. 4) do not show any temperature trend from W-SW to E-NE. They present an overall Th mode of $95 \pm 10^{\circ} \mathrm{C}$. All the samples present a small number of FIs that underwent re-equilibration. These FI data are graphically represented in the Th frequency histogram by a tail toward higher temperatures $\left(>120-130^{\circ} \mathrm{C}\right.$; Fig. 11). Most Th values fall within the range $70-120^{\circ} \mathrm{C}$ (Fig. 11), according to a normal distribution.

Only samples from Monte Gargaruso well showed a behavior suggesting clear thermal re-equilibration and/or leakage. Indeed, most of these inclusions homogenized at temperatures higher than $200^{\circ} \mathrm{C}$ (Fig. 11), more than $90^{\circ} \mathrm{C}$ higher than the modal values of the other samples representing the same fluid event (based on the geochemical similarities, Gabellone $\mathrm{T}$, Iannace A, Gasparrini $\mathrm{M}$, submitted; see also Fig. 7). Moreover, repeated Th measurements on the same FIs gave progressively higher Th values. Samples from Monte Gargaruso probably underwent overheating during drilling operations from the well. 

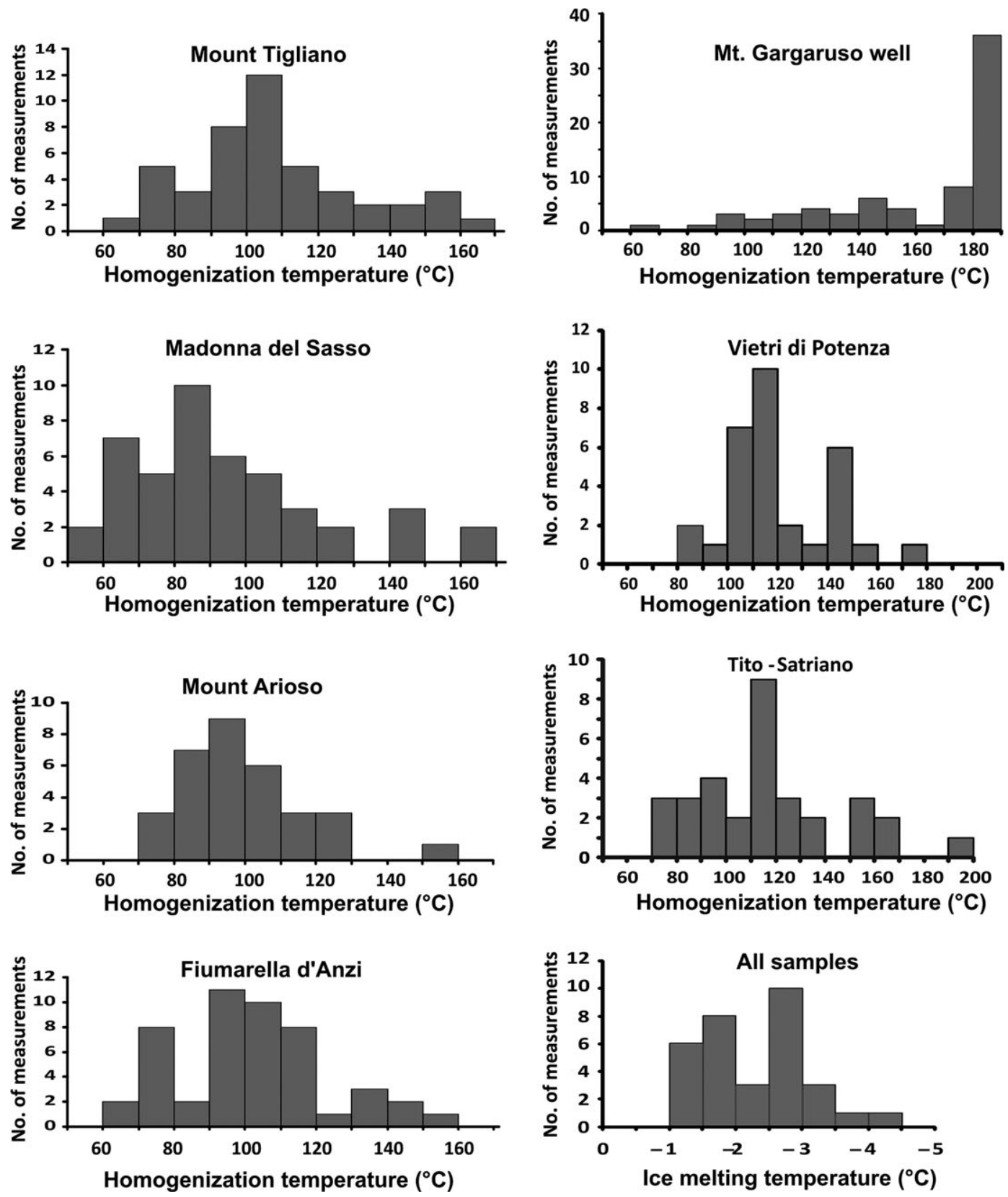

Fig. 11. Histograms showing the frequency distribution of homogenization temperatures (Th) and ice-melting temperatures (diagram in the bottom right) values of dolomite samples from different localities (see location in Fig. 4). Samples from Monte Gargaruso well underwent thermal re-equilibration, represented by the tail of Th values toward high temperatures. Values in the interval $180-190^{\circ} \mathrm{C}$ are minimum values of Th, as the corresponding fluid inclusions homogenized at higher temperatures (not reported for graphical reasons).

The two dolomite samples located northwest to the transect record slightly higher temperatures (approximately $20^{\circ} \mathrm{C}$ ) compared with dolomites along the transect and display an overall Th mode of $115^{\circ} \mathrm{C}$ (Fig. 11).

Ranges in Tmi values are limited in all dolomite samples (including those that possibly experienced thermal reequilibration) and present an overall range between -1.1 and $-4^{\circ} \mathrm{C}$, with a broad mode of $-2.5^{\circ} \mathrm{C}$ (Fig. 11).
These values correspond to a range of salinity between 1.9 and $6.4 \mathrm{wt} \% \mathrm{NaCl}$ eq (mean of $3.7 \mathrm{wt} \% \mathrm{NaCl}$ eq, Fig. 10).

Homogenization temperatures of FIs obtained with microthermometry represent only the minimum trapping temperatures $(\mathrm{Tt})$. Real trapping temperatures of FIs were obtained after applying a 'pressure correction'. For this calculation, composition of the inclusions and the pressure at 

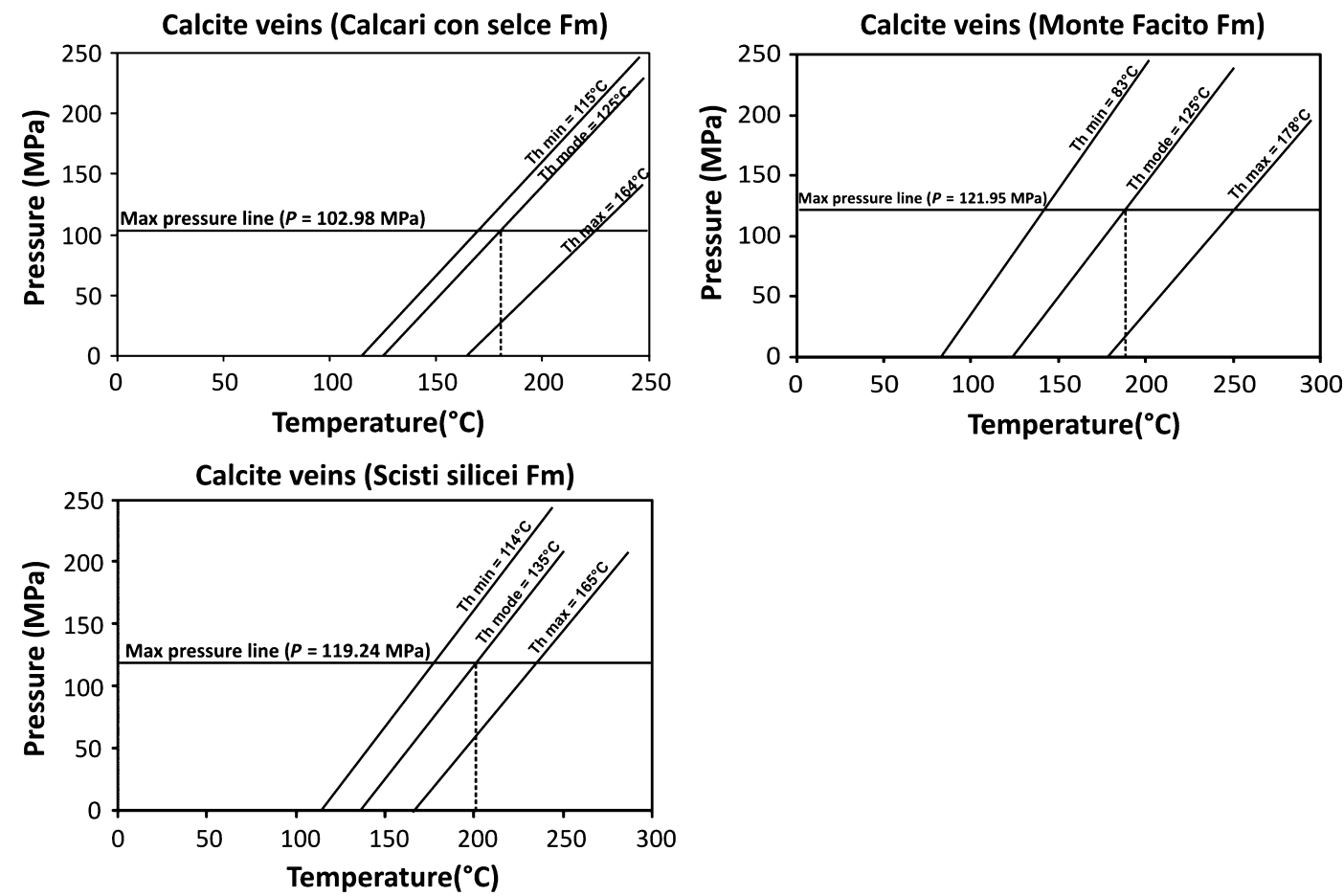

Fig. 12. Pressure-temperature (P-T) plots illustrating the 'pressure correction' for the homogenization temperature (Th) of the calcite veins fluid inclusions (FIs) from different formations of the Lagonegro succession. The isochores (constructed for mode, minimum and maximum Th values) were intersected with the maximum pressure line. The intersection points define the maximum P-T conditions for Fls trapping.
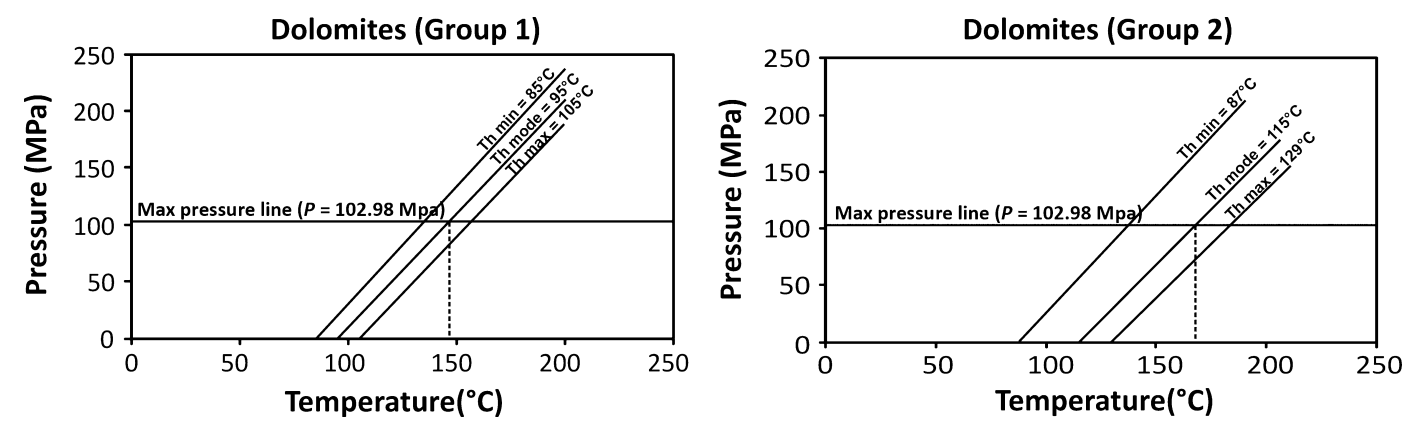

Fig. 13. Pressure-temperature (P-T) plots illustrating the 'pressure correction' for the homogenization temperature (Th) of the dolomite fluid inclusions (FIs). The isochores (constructed for mode, minimum and maximum Th values) were intersected with the maximum pressure line. The intersection points define the maximum P-T conditions for Fls trapping.

the time of entrapment must be known, and the latter must be determined with independent methods.

The integrated analysis of various thermal indicators suggests that the Lagonegro Basin units experienced a significant tectonic burial (in the range of $4-5 \mathrm{~km}$ ) as a result of thrusting (Aldega et al. 2005). Furthermore, the several hundreds of meters thick, Lower Cretaceous to Paleogene top part of the Lagonegro Basin succession is dominated by shales that are likely to have constituted an efficient seal in the footwall to the Apennine platform carbonate units.
Fluid overpressure buildup within the Lagonegro Basin succession is indicated by widespread evidence of hydraulic fracturing and bedding-parallel calcite veins displaying classic 'cone in cone' fiber growth (Mazzoli 1992). Taking into account all these features, a quasi-lithostatic fluid pressure regime is likely to have been dominant within the Lagonegro Basin units following the first, regional thrusting phase. Therefore, in this study, a lithostatic gradient has been assumed for the pressure correction of fluid inclusion data. As argued by Corrado et al. (2010), this is more sat- 


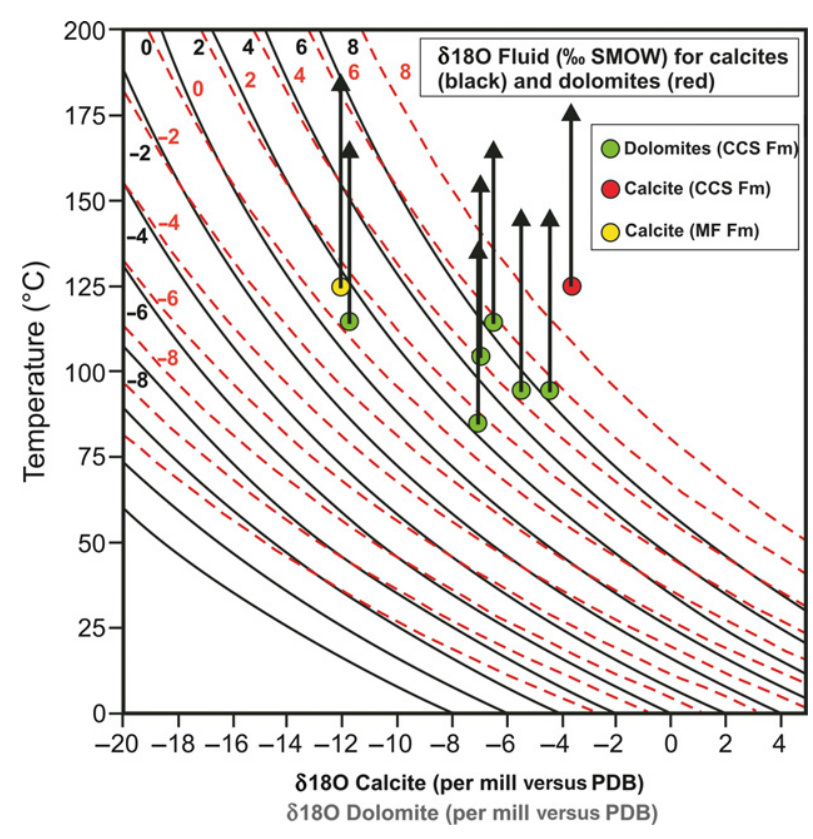

Fig. 14. Plot of precipitation temperature versus $\delta^{18} \mathrm{O}$ values of the calcite veins from the Monte Facito (MF) and the Calcari con selce (CCS) Formations (Fms), and of the dolomites from the CCS Fm. The fractionation equation of Friedman \& O'Neil (1977) and Land (1983) were used to calculate the $\delta^{18} \mathrm{O}_{\text {SMOW }}$ composition of fluids in equilibrium with calcites (continue black curves) and dolomites (dotted red curves), respectively. Arrows above the dots indicate the maximum possible 'pressure correction' for each sample.

isfactory, in terms of accuracy of pressure estimates, than the assumption of hydrostatic pressure (Iannace et al. 2012)

Maximum burials of $3.8,4.4$, and $4.5 \mathrm{~km}$ were experienced during the deformation history, respectively, by the CCS, the MF, and the SS Fms (Aldega et al. 2005; Mazzoli et al. 2008) in the sampling localities. According to a lithostatic pressure gradient of $27.1 \mathrm{MPa} / \mathrm{km}$ (assuming a sedimentary rock density of $2.7 \mathrm{~g} / \mathrm{cm}^{3}$ ), these peak burial depths would have corresponded to maximum pressures of 102.98, 119.24, and 121.95 MPa.

Isochores were constructed for the Th mode, minimum, and maximum values of the different samples in pressuretemperature (P-T) diagrams. Concerning the dolomite samples, the 'pressure correction' was applied separately to dolomites of Group 1 and Group 2. However, the overall mean salinity (3.7 wt\% $\mathrm{NaCl}$ eq) was used for the slope isochores calculations of both groups, as no significant salinity difference was found between the FIs of the two groups.

In the obtained P-T diagrams (Figs 12 and 13), the maximum trapping temperatures of FIs are given by the intersections between the constructed isochores and the maximum pressure line. The true values of trapping temperatures (by assuming thermal equilibrium between the fluid and the rocks) must fall between the maximum and the homogenization conditions.
Pressure correction calculations for Th values from calcite and quartz veins of the SS Fm suggest maximum trapping temperatures of $\mathrm{Th}+65^{\circ} \mathrm{C}$ (e.g. for the precorrection modal value of $135^{\circ} \mathrm{C}$, we calculate a $\mathrm{Tt} \max$ of $200^{\circ} \mathrm{C}$; Fig. 12), while calcite and quartz veins from the CCS Fm precipitated at maximum temperatures of $\mathrm{Th}+55^{\circ} \mathrm{C}$ (modal value $\mathrm{Tt} \max =180^{\circ} \mathrm{C}$; Fig. 12).

The calculated 'pressure correction' for calcite and quartz veins in the MF $\mathrm{Fm}$ gave maximum trapping temperatures around $189^{\circ} \mathrm{C}\left(\mathrm{Th}+64^{\circ} \mathrm{C}\right.$; Fig. 12).

The calculated maximum trapping temperatures for all dolomite samples belonging to the two considered groups are equal to $\mathrm{Th}+50 / 54^{\circ} \mathrm{C}$. Therefore, maximum trapping temperatures for FIs from dolomites of Group 1 fall between 135 and $157^{\circ} \mathrm{C}$ (mode at $148^{\circ} \mathrm{C}$; Fig. 13), whereas FIs from dolomites belonging to the Group 2 were possibly trapped at temperatures between 137 and $183^{\circ} \mathrm{C}$ (mode at $168^{\circ} \mathrm{C}$; Fig. 13).

\section{DISCUSSION}

\section{Source of fluids for the Lagonegro dolomites}

Detailed structural analysis carried out over the past twenty years allowed us to obtain a comprehensive picture at various scales of the superposed structures developed in the Lagonegro Basin units (Mazzoli 1992, 1995; Mazzoli \& Carnemolla 1993; Mazzoli et al. 2001a,b). A first deformation stage, dominated by roughly E-W shortening, produced buckling of the Lagonegro Basin succession in the footwall to the Apenninic platform carbonates. Calcite and quartz veins developed during this stage as a result of bedding-scale strain associated with the folding mechanisms controlling the buckling process (flexural slip/flow, tangential-longitudinal strain). A second deformation stage, involving NNE-SSW shortening, produced minor refolding and crenulation cleavage development, as well as significant top-to-the-NNE, out of sequence re-embrication of the Lagonegro Basin units. The Marsico Nuovo Thrust, which developed during this stage, appears to have acted as a major low-angle fault zone, which controlled fluid channeling and partial dolomitization of the micritic limestones of the CCS Fm.

According to Iannace et al. (2012), dolomitization in the Pignola area occurred when the exhumation was already begun, at $3-4 \mathrm{~km}$ of burial. This process was driven by tectonically induced fluid flow, during the second compressional phase of the southern Apennines.

The homogenization temperatures measured for dolomites within this regional study of the Lagonegro succession (Groupl: $95 \pm 10^{\circ} \mathrm{C}$, Group2: $115^{\circ} \mathrm{C}$ ) indicate the action of warm and reducing fluids and provide further evidence for the burial origin of dolomitizing fluids. 
Maximum trapping temperatures of dolomites (148$168^{\circ} \mathrm{C}$ ), obtained after applying a lithostatic 'pressure correction', support previously reported evidence that dolomitizing fluids were cooler than temperatures attained within the rock at peak burial $\left(180-200^{\circ} \mathrm{C}\right)$ during the first deformation stage in the Miocene.

Within the Pignola-Val d'Agri area, dolomites located to the northwest (Group 2) of the transect (Group 1) present slightly higher (approximately $20^{\circ} \mathrm{C}$ ) Th values. No thermometric data for the former sampling localities (Group 2) are available in the literature; therefore, the maximum burial attained by the succession in the northwest area is unconstrained. The 'pressure correction' for these samples assumes that the northwest area reached the same maximum burial $(3.8 \mathrm{~km})$ as the transect area. However, it is possible that the northwest area reached greater depths which would produce this temperature difference. The northwest area is located closer to the thrust that juxtaposed the Apenninic platform units onto the Lagonegro units (Fig. 4) and thus possibly underwent a higher tectonic loading.

Calcite and quartz veins formed during both shortening phases are characterized by high temperatures and lowsalinity fluids. To constrain the oxygen isotope compositions of the parent fluids of these veins, we plotted the obtained homogenization temperatures (mode values) against calcite $\delta^{18} \mathrm{O}$ values (Fig. 14). This plot estimates a value of approximately 4 SMOW (or higher than 8 if we consider the maximum 'pressure correction') for the MF Fm sample and approximately 12 SMOW (or 16 if we consider the maximum 'pressure correction') for the CCS Fm sample. Both are typical values of formation waters.

$\mathrm{O}, \mathrm{C}$, and $\mathrm{Sr}$ stable isotope values for the calcite veins in the CCS Fm, overlap the values of the host limestones and indicate a closed system, dominated by the host rock. The calcite veins in the MF Fm posses highly depleted $\delta^{18} \mathrm{O}$ and radiogenically enriched $\mathrm{Sr}$ values. These data indicate a major diagenetic evolution of the fluid and interaction with siliciclastic sediments of the host rock. The syntectonic calcite veins from the tectonic mélange have a carbon and strontium isotopes composition in line with the one of the Miocene seawater (Zachos et al. 2001; McArthur \& Howarth 2004), whereas their $\delta^{18} \mathrm{O}$ values are more negative relative to the coeval seawater. This lighter oxygen isotope composition is typical of a burial environment.

According to Iannace et al. (2012), the dolomitizing fluids in the Lagonegro succession could have been squeezed out from two potential sources: the surrounding clastic formations of Mesozoic age (i.e., Monte Facito and Galestri) or the deeper tectonic mélange units of Miocene age. A further potential source is the underthrust fine-clastic series of Pliocene age, which occur on top of the Apulian Mesozoic-Tertiary shallow-water carbonates.
The $\delta^{18} \mathrm{O}_{\text {SMOW }}$ values obtained for dolomites within this study (Fig. 14) fall between those of marine and clastic formation waters with a range of $1-6(5-11$ if we consider the maximum 'pressure correction'). However, the low salinity of these fluids, inferred from the fluid inclusion analyses reported here for dolomite samples (range of 1.9$6.4 \mathrm{wt} \% \mathrm{NaCl} \mathrm{eq}$ ), is unusual for clastic formation waters and would require their dilution by fresh water. This may occur as a result of meteoric input or fresh water release during clay diagenesis. Circulation of meteoric fluids along thrust zones has been documented in different FTBs during their deformation history (Katz et al. 2006; Travé et al. 2007; Ronchi et al. 2010; Evans \& Fischer 2012 and references therein). These fluids infiltrate into the already emerged chain, possibly mix with basinal brines and eventually flow up along the major thrust faults. For the Lagonegro case study, we exclude meteoric input due to lack of support from geochemical data (positive $\delta^{18} \mathrm{O}_{\text {SMOW }}$ values) and because partial dolomitization of the CCS Fm occurred when the succession was still deeply buried (i.e., $3-4 \mathrm{~km}$ depth), and thus, is unlikely to have been reached by meteoric fluids.

Low-salinity fluids could be derived from dilution of saline pore waters by fresh waters delivered during smectiteillite transformation at depth (Kastner et al. 1991; Fitts \& Brown 1999). This latter process is common in accretionary wedges and generally occurs at a depth range of 3.5-7 km and at elevated temperatures around $120-165^{\circ} \mathrm{C}$ (Dählmann \& De Lange 2003). Both conditions (i.e., maximum burial of about $4 \mathrm{~km}$ and temperature peak of 130 $160^{\circ} \mathrm{C}$ ) were attained, while deformation of the Lagonegro units was underway (Corrado et al. 2005). Water released during smectite to illite conversion is typically characterized by positive $\delta^{18} \mathrm{O}_{\text {SMOW }}$ signatures (i.e., 5-10, Suchecki \& Land 1983; Vrolijk et al. 1988; Taylor 1990; Dählmann \& De Lange 2003). Thus, the positive signature inferred for the dolomitizing fluids would be in agreement with this clay transformation. However, because of prolonged waterrock interactions during deep burial, we would expect pore waters expelled from the surrounding fine-clastic formations to have been more radiogenic than our data suggest for the Lagonegro dolomitizing fluids.

Geochemical data advocates for the second alternative hypothesis of Iannace et al. (2012), that is, that the fluid source for the Lagonegro dolomites is represented by modified marine pore waters expelled from the Miocene formations within the underlying tectonic mélange. The latter represents the decollement level between the southern Apennines FTB units and the underlying Apulian platform units. This mélange consists mainly of intensely deformed and overpressured deepwater mudstones and siltstones of Miocene to Lower Pliocene age, including blocks of material derived from the overlying allochthon (Mazzoli et al. 2001a; Butler et al. 2004; Shiner et al. 
2004). Sr isotope data of the studied dolomites display values close to those of Miocene seawater (McArthur \& Howarth 2004) and support the hypothesis that dolomitizing fluids were sourced from the tectonic mélange. Moreover, $\mathrm{Sr}$ stable isotopes and oxygen stable isotope values of syntectonic calcite veins, sampled in the tectonic mélange, present values very close to those of the dolomites (Figs 7 and 8).

Syntectonic expulsion of fluids along the basal décollement of the southern Apennines accretionary wedge has been documented by Roure et al. (1991). Is it possible that these fluids, circulating in the tectonic mélange and generating syntectonic calcite veins, were also responsible for the partial dolomitization of the limestones of the CCS Fm.

The low salinity detected in the studied dolomites (mean of $3.7 \mathrm{wt} \% \mathrm{NaCl}$ eq) is relatively unusual for burial dolomites, which generally originate from very saline formation waters (i.e., Gasparrini et al. 2006). On a global scale, most high temperature, saddle dolomites are thought to have precipitated from brines with average salinities between 12 and 25 wt\% $\mathrm{NaCl}$ eq (Davies \& Smith 2006, and references therein). These salinities are probably derived from postevaporite sources with varying modification by seawater, fresh water, and by interaction with basement or siliciclastic rocks. It is noteworthy that the occurrence of low-salinity fluids in the Lagonegro units is consistent with the record of very low salinity (generally less saline than seawater) in present-day formation waters encountered at high depths in the wells of the Val d'Agri oil field (Paola Ronchi (ENI), personal communication).

\section{Saline versus nonsaline fluids in fold-and-thrust belts: Lagonegro versus other case histories}

Further examples of syntectonic dolomitization by lowsalinity fluids are known, especially in Italy. A 'squeegeetype' drive for fluids with salinities from seawater to brackish caused dolomitization in the Southern Alps. These low salinities have been explained as a mixing of meteoric waters with deep basinal brines (Ronchi et al. 2010; Di Cuia et al. 2011). In Cretaceous, shallow-water carbonates from the Panormide platform, exposed in north-central Sicily, hot $\left(\mathrm{Th}=130-180^{\circ} \mathrm{C}\right)$ and low saline (lower than $4.2 \mathrm{wt} \% \mathrm{NaCl}$ eq) fluids caused the precipitation of small volumes of dolomite cement. These display high $\delta^{18} \mathrm{O}_{\text {SMOW }}$ signatures $(6-14)$ and are interpreted to have migrated during FTB development in Middle Miocene. Their geochemical signatures were interpreted to be the result of clay dewatering reactions (Dewever et al. 2010).

By contrast, tectonically driven fluid flow of highly saline fluids is documented in other FTBs, for example, within the Iberian range, the Albanides, and the central Apen- nines (Marfil et al. 2005; Vilasi et al. 2009; Ronchi et al. 2010). In these cases, high-salinity fluids are explained by the presence of deeper evaporite-bearing stratigraphic levels, along the décollement during thrusting.

The salinity differences in the dolomitizing fluids of the Southern Alps and the central Apennines were considered by Ronchi et al. (2010) to be related to differences in subaerial relief within the two belts during dolomite precipitation. According to these authors, the higher relief of the Alpine belt during collision allowed the infiltration of meteoric water, while the Apennines were still submerged during dolomitization, preventing meteoric recharge. The new data from this study of Lagonegro and its comparison with similar case studies of syntectonic dolomitization allow us to suggest a more consistent hypothesis, that fluid compositions within these systems are more strongly controlled by the lithologies found along major décollements than the relief of the belt.

The hypothesis of fluid compositional dependence on water-rock interaction along major décollements during 'squeegee' fluid flow has already been proposed by Dewever (2008). In the Albanides, there is evidence for expulsion of highly saline fluids (Vilasi et al. 2009) along the main décollement above Triassic evaporites. Likewise, in the central Apennines, data of Ronchi et al. (2010) point to the action of saline formation waters, which were probably sourced from the evaporites of the Burano Anhydrites Formation. On the contrary, the southern Apennines and others FTBs (i.e., Southern Alps and Sicily), whose décollement horizons border siliciclastics rocks rather than evaporites, are characterized by low-salinity fluids (Dewever et al. 2010; Ronchi et al. 2010). In these latter cases, the fluids could derive from clays dewatering.

High fluxes of low-salinity fluids along décollements at depth are documented in some currently active accretionary wedges (Barbados, Nankai, Peru), and the source of these fluids might include dilution by clay dehydration reactions (Suess et al. 1988; Kastner et al. 1991; Le Pichon et al. 1991; Vrolijk et al. 1991).

Syntectonic dewatering of sedimentary units, characterized by low saline fluids, is also documented along décollements and thrust faults in the Sicilian FTB, where hydrofracturing and mineralized veins developed (Larroque et al. 1996). In this example, smectite to illite transformation and deep metamorphic reactions are considered to be the most likely causes for the low salinities. Another example of syntectonic quartz and calcite veins, generated from connate formation waters with low salinity (near seawater), comes from the Hudson Valley FTB (Catskill, New York; Selleck \& Zangrilli 2001). Here, the waters did not interact with evaporites, and low salinities are due to the presence of a significant volume of water derived from the dehydration of hydrous minerals within local clastic units (Selleck \& Zangrilli 2001). 


\section{CONCLUSIONS}

A multidisciplinary study on syntectonic, late burial dolomites from the Upper Triassic Lagonegro Basin succession of the southern Apennines FTB was carried out to discriminate between possible dolomitizing fluids sources (i.e., siliciclastics rocks of the Monte Facito Fm or siliciclastics rocks of the deeper tectonic mélange units).

The results of fluid inclusion analysis show that fluids channeled along the southern Apennines thrust zones during the FTB tectonic evolution was characterized by low salinities, close or lower than that of seawater, suggesting that the fluids did not interact with evaporites. The involvement of low-salinity fluids in burial dolomitization is unusual, but has been recognized in other FTBs, which are mostly located in Italy.

We identify tectonic mélange siltstones and mudstones beneath the major décollement of the southern Apennines FTB as the probable source for the fluids that drove dolomitization within Lagonegro units. This is supported by a close match between the isotopic signatures ( $\mathrm{O}$ and $\mathrm{Sr}$ stable isotopes) of syntectonic calcite veins from the tectonic mélange and Lagonegro dolomites.

Fluid expulsion along major décollement horizons during FTB deformation has been documented in a number of case studies. Here, it is suggested that the nature of these fluids is dependent on the lithology along the décollement and in particular low-salinity fluids derive from siliciclastics rocks. These fluids can cause dolomitization of carbonate successions (different examples have been reported in Italy) and modify the petrophysical properties of the precursor limestones.

\section{ACKNOWLEDGEMENTS}

This publication benefitted from grants of the National Research Project PRIN2009 N73SR4 (Responsible: A. Iannace). We acknowledge Dr. Dieter Buhl, for performing most geochemical analyses at the Isotopen-labor of the Institut fur Geologie, Mineralogie und Geophysik of the Ruhr University (Bochum, Germany). We are grateful to Prof. Michael Joachimski (University of Erlangen-Nuremberg, Germany) for analyzing isotopes of two additional samples, and to Dr. Ilenia Arienzo for her help during Sr isotope analyses in the Naples laboratory. We thank Eni S.p.a. for providing cuttings from the Monte Gargaruso well. TG is very grateful to her friend Miles Fraser who improved the English form of the original manuscript. We thank the three reviewers for their constructive comments.

\section{REFERENCES}

Aldega L, Corrado S, Di Leo P, Giampaolo C, Invernizzi C, Martino C, Mazzoli S, Schiattarella M, Zattin M (2005) The
Southern Apennines case history: thermal constraints and reconstruction of tectonic and sedimentary burials. Atti Ticinensi di Scienze della Terra, 10, 45-53.

Amato A (2000) Estimating Pleistocene tectonic uplift rates in the southeastern Apennines (Italy) from erosional land surfaces and marine terraces. In: Geomorphology, Human Activity and Global Environmental Change (ed. Slaymaker O), pp. 67-87. International Association of Geomorphologists Publication, New York.

Ascione A, Cinque A (1999) Tectonics and erosion in the longterm relief history of southern Apennines (Italy). Zeitschrift für Geomorphologie, Supplement Band, 117, 1-15.

Ascione A, Caiazzo C, Cinque A (2007) Recent faulting in Southern Apennines (Italy): geomorphic evidence, spatial distribution and implications for rates of activity. Bollettino della Società Geologica Italiana, 126, 293-305.

Ascione A, Ciarcia S, Di Donato V, Mazzoli S, Vitale S (2012) The Pliocene-Quaternary wedge-top basins of southern Italy: an expression of propagating lateral slab tear beneath the Apennines. Basin Research, 24, 456-74.

Bakker RJ (2003) Package FLUIDS 1. Computer programs for analysis of fluid inclusion data and for modelling bulk fluid properties. Chemical Geology, 194, 3-23.

Bakker RJ (2009) Package FLUIDS. Part 3: correlations between equation of state, thermodynamics and fluid inclusions. Geofluids, 9, 3-23.

Bodnar RJ (1993) Revised equation and table for determining the freezing point depression of $\mathrm{H}_{2} \mathrm{O}-\mathrm{NaCl}$ solutions. Geochimica et Cosmochimica Acta, 57, 683-4.

Bodnar RJ, Vityk MO (1994) Interpretation of microthermometric data for $\mathrm{H}_{2} \mathrm{O}-\mathrm{NaCl}$ fluid inclusions. In: Fluid Inclusions in Minerals: Methods and Applications (eds De Vivo B, Frezzotti ML), pp. 117-30. Virginia Tech, Blacksburg, VA.

Bussolotto M, Benedicto A, Invernizzi C, Micarelli L, Plagnes V, Deiana G (2007) Deformation features within an active fault zone in carbonate rocks: the Gubbio fault (Central Apennines, Italy). Journal of Structural Geology, 29, 201737.

Butler RWH, Mazzoli S, Corrado S, De Donatis M, Di Bucci D, Gambini R, Naso G, Nicolai C, Scrocca D, Shiner P, Zucconi $\mathrm{V}$ (2004) Applying thick-skinned tectonic models to the Apennine thrust belt of Italy: limitations and implications. In: Thrust Tectonics and Petroleum Systems (ed. McClay KR), pp. 647-67. American Association Petroleum Geologists Memoir, Tulsa, OK.

Caiazzo C, Ascione A, Cinque A (2006) Late Tertiary-Quaternary tectonics of the Southern Apennines (Italy): new evidence from the Tyrrhenian slope. Tectonophysics, 421, 23-51.

Carpenter AB (1978) Origin and chemical evolution of brines in sedimentary basins. In: 13th Industrial Minerals Forum (eds Johnson KS, Russell JR), vol 79, pp. 60-70. Oklahoma Geological Survey Circular, Norman, OK.

Casero P, Roure F, Vially R (1991) Tectonic framework and petroleum potential of the southern Apennines. In: Generation, Accumulation, and Production of Europe's Hydrocarbons (ed. Spencer AM), pp. 381-7. EAPG Special Publication, Oxford University Press, Oxford.

Cello G, Guerra I, Tortorici L, Turco E, Scarpa R (1982) Geometry of the neotectonic stress field in southern Italy: geological and seismological evidence. Journal of Structural Geology, 4, 385-93.

Cello G, Invernizzi C, Mazzoli S, Tondi E (2001) Fault properties and fluid flow patterns from Quaternary faults in the Apennines, Italy. Tectonophysics, 336, 63-78. 
Ciarapica G, Cirilli S, Panzanelli Fratoni R, Passeri L, Zaninetti L (1990) The Monte facito formation (Southern Apennines). Bollettino della Società Geologica Italiana, 109, 135-42.

Ciarcia S, Mazzoli S, Vitale S, Zattin M (2012) On the tectonic evolution of the Ligurian accretionary complex in southern Italy. Geological Society of America Bulletin, 123, 463-83.

Cinque A, Patacca E, Scandone P, Tozzi M (1993) Quaternary kinematic evolution of the Southern Apennines, relationships between surface geological features and deep lithospheric structures. Annali di Geofisica, 36, 249-60.

Corrado S, Invernizzi C, Mazzoli S (2002) Tectonic burial and exhumation in a foreland fold and thrust belt: the Monte Alpi case history (Southern Apennines, Italy). Geodinamica Acta, 15, 159-77.

Corrado S, Aldega L, Di Leo P, Giampaolo C, Invernizzi C, Mazzoli S, Zattin M (2005) Thermal maturity of the axial zone of the southern Apennines fold-and thrust-belt (Italy) from multiple organic and inorganic indicators. Terra Nova, 17, 5665.

Corrado S, Invernizzi C, Aldega L, D’Errico M, Di Leo P, Mazzoli S, Zattin M (2010) Testing the validity of organic and inorganic thermal indicators in different tectonic settings from continental subduction to collision: the case history of the Calabria-Lucania border (Southern Apennines, Italy). Journal of the Geological Society of London, 167, 985-99.

Dählmann A, De Lange GJ (2003) Fluid-sediment interactions at Eastern Mediterranean mud volcanoes: a stable isotope study from ODP Leg 160. Earth and Planetary Science Letters, 212, 377-91.

Davies GR, Smith LBJ (2006) Structurally controlled hydrothermal dolomite reservoir facies: an overview. American Association of Petroleum Geologists Bulletin, 90, 1641-90.

Dewever B (2008) Diagenesis and Fluid Flow in the Sicilian Foldand-Thrust Belt. PhD Thesis, KU-Leuven, Heverlee.

Dewever B, Berwouts I, Swennen R, Breesch L, Ellam RM (2010) Fluid flow reconstruction in karstified Panormide platform limestones (northern-central Sicily): implications for hydrocarbon prospectivity in the Sicilian fold and thrust belt. Marine and Petroleum Geology, 27, 939-58.

Dewey JF, Helman ML, Turco E, Hutton DWH, Knott SD (1989) Kinematics of the western Mediterranean. In: Alpine Tectonics (eds Coward MP, Dietrich D, Park RG), pp. 265-83. Geological Society of London Special Publication, London.

Di Cuia R, Riva A, Scifoni A, Moretti A, Spötl C, Caline B (2011) Dolomite characteristics and diagenetic model of the Calcari Grigi Group (Asiago Plateau, Southern Alps - Italy): an example of multiphase dolomitization. Sedimentology, 58, 1347 69

Di Luzio E, Mele G, Tiberti MM, Cavinato G, Parotto M (2009) Moho deepening and shallow upper crustal delamination beneath the central Apennines. Earth and Planetary Science Letters, 280, 1-12.

Evans MA, Fischer MP (2012) On the distribution of fluids in folds: A review of controlling factors and processes. Journal of Structural Geology, 44, 2-24.

Fitts TG, Brown KM (1999) Stress-induced smectite dehydration: ramifications for patterns of freshening and fluid expulsion in the Northern Barbados accretionary wedge. Earth and Planetary Science Letters, 172, 179-97.

Friedman I, O'Neil JR (1977) Compilation of stable isotope fractionation factors of geochemical interest. In: Data of Geochemistry (ed. Fleischer M), pp. 1-12. US Geological Survey Professional Paper, Reston, VA.
Gasparrini M, Bakker RJ, Bechstädt T (2006) Characterization of dolomitizing fluids from the Carboniferous of the Cantabrian Zone (NW Spain): a fluid inclusion study with cryo-raman spectroscopy. Journal of Sedimentary Research, 76, 1304-22.

Hardie LA (1990) The roles of rifting and hydrothermal $\mathrm{CaCl}_{2}$ brines in the origin of potash evaporites: an hypothesis. American Journal of Science, 290, 43-106.

Hippolyte JC, Angelier J, Roure F (1994) A major geodynamic change revealed by Quaternary stress patterns in the Southern Apennines (Italy). Tectonophysics, 230, 199-210.

Hitzman MW, Allan JR, Beaty DW (1998) Regional dolomitization of the Waulsortian limestone in southeastern Ireland: evidence of large scale fluid flow driven by the Hercynian orogeny. Geology, 26, 547-50.

Iannace A, Gasparrini M, Gabellone T, Mazzoli S (2012) Late dolomitization in basinal limestones of the southern Apennines fold and thrust belt (Italy). Oil \& Gas Science and Technology Revue d'IFP Energies nouvelles, 67, 59-75.

Improta L, Corciulo M (2006) Controlled source nonlinear tomography: a powerful tool to constrain tectonic models of the Southern Apennines orogenic wedge. Italy Geology, 34, 941-4.

Kastner M, Elderfield H, Martin JB (1991) Fluids in convergent margins - What do we know about their composition, origin, role in diagenesis and importance for oceanic chemical fluxes. Philosophical Transactions of the Royal Society of London Series a-Mathematical Physical and Engineering Sciences, 335, 243-59.

Katz DA, Eberli GP, Swart PK, Smith LBJ (2006) Tectonichydrothermal brecciation associated with calcite precipitation and permeability destruction in Mississippian carbonate reservoirs, Montana and Wyoming. American Association of Petroleum Geologists Bulletin, 90, 1803-41.

Korte C, Kozur HW, Veizer J (2005) $\delta^{13} \mathrm{C}$ and $\delta^{18} \mathrm{O}$ values of Triassic brachiopods and carbonate rocks as proxies for coeval seawater and palaeotemperature. Palaeogeography, Palaeoclimatology, Palaeoecology, 226, 287-306.

Krumgalz BS, Pogorelsky R, Pitzer KS (1996) Volumetric properties of single aqueous electrolytes from zero to saturation concentrations at $298,15 \mathrm{~K}$ represented by Pitzer's IonInteraction Equation. Journal of Physical and Chemistry Reference Data, 25, 663-89.

Land LS (1983) The application of stable isotopes to studies of the origin of dolomite and to problems of diagenesis of clastic sediments. In: Stable Isotopes in Sedimentary Geology (eds Arthur MA, Anderson TF, Kaplan IR, Veizer J, Land LS), pp. 4.14.22. SEPM Short Course, Tulsa, OK.

Larroque C, Guilhaumou N, Stephan JF, Roure F (1996) Advection of fluids at the front of the Sicilian Neogene subduction complex. Tectonophysics, 254, 41-55.

Lawn BR, Wilshaw TR (1975) Fracture of Brittle Solids. Cambridge University Press, Cambridge.

Le Pichon X, Henry P, and the Kaiko-Nankai Scientific Crew (1991) Water budgets in accretionary wedges: a comparison. Royal Society of London Philosophical Transactions, 335, 315-30.

Macchiavelli C, Mazzoli S, Megna A, Saggese F, Santini S, Vitale S (2012) Applying the Multiple Inverse Method to the analysis of earthquake focal mechanism data: new insights into the active stress field of Italy and surrounding regions. Tectonophysics, 580, 124-49.

Marfil R, Caja MA, Tsige M, Al-Aasm IS, Martin-Crespo T, Salas $\mathrm{R}$ (2005) Carbonate-cemented stylolites and fractures in the Upper Jurassic limestones of the Eastern Iberian Range, Spain: a record of paleofluids composition and thermal history. Sedimentary Geology, 178, 237-57. 
Mazzoli S (1992) Structural analysis of the Mesozoic Lagonegro Units in SW Lucania (Southern Italian Apennines). Studi Geologici Camerti, 12, 117-46.

Mazzoli S (1995) Strain analysis in Jurassic argillites of the Monte Sirino area (Lagonegro Zone, southern Apennines, Italy) and implications for deformation paths in pelitic rocks. Geologische Rundschau, 84, 781-93.

Mazzoli S, Carnemolla S (1993) Effects of the superposition of compaction and tectonic strain during folding of a multilayer sequence - model and observations. Journal of Structural Geology, 15, 277-91.

Mazzoli S, Di Bucci D (2003) Critical displacement for normal fault nucleation from en-échelon vein arrays in limestones: a case study from the southern Apennines (Italy). Journal of Structural Geology, 25, 1011-20.

Mazzoli S, Helman M (1994) Neogene patterns of relative plate motion for Africa-Europe: some implications for recent central Mediterranean tectonics. Geologische Rundschau, 83, 464-8.

Mazzoli S, Corrado S, De Donatis M, Scrocca D, Butler RWH, Di Bucci D, Naso G, Nicolai C, Zucconi V (2000) Time and space variability of "thin-skinned" and "thick-skinned" thrust tectonics in the Apennines (Italy). Rendiconti Lincei Scienze Fisiche e Naturali, 11, 5-39.

Mazzoli S, Barkham S, Cello G, Gambini R, Mattioni L, Shiner P, Tondi E (2001a) Reconstruction of continental margin architecture deformed by the contraction of the Lagonegro Basin, southern Apennines, Italy. Journal of the Geological Society of London, 158, 309-19.

Mazzoli S, Zampetti V, Zuppetta A (2001b) Very lowtemperature, natural deformation of fine grained limestone: a case-study from the Lucania region, southern Apennines, Italy. Geodinamica Acta, 14, 213-30.

Mazzoli S, Invernizzi C, Marchegiani L, Mattioni L, Cello G (2004) Brittle-ductile shear zone evolution and fault initiation in limestones, Monte Cugnone (Lucania), southern Apennines, Italy. Geological Society of London, Special Publication, 224, 353-73.

Mazzoli S, Aldega L, Corrado S, Invernizzi C, Zattin M (2006) Pliocene-Quaternary thrusting, syn-orogenic extension and tectonic exhumation in the Southern Apennines (Italy): insights from the Monte Alpi area. In: Styles of Continental Contraction (eds Mazzoli S, Butler RWH), pp. 55-77. Geological Society of America, Denver, CO. Special Paper.

Mazzoli S, D’Errico M, Aldega L, Corrado S, Invernizzi C, Shiner P, Zattin M (2008) Tectonic burial and 'young' (< $10 \mathrm{Ma}$ ) exhumation in the southern Apennines fold and thrust belt (Italy). Geology, 36, 243-6.

Mazzoli S, Szaniawski R, Mittiga F, Ascione A, Capalbo A (2012) Tectonic evolution of Pliocene-Pleistocene wedge-top basins of the southern Apennines: new constraints from magnetic fabric analysis. Canadian Journal of Earth Sciences, 49, 492-509.

McArthur JM, Howarth RJ (2004) Strontium isotope Stratigraphy. In: A Geological Time Scale 2004 (eds Gradstein FM, Ogg JG, Smith AG), pp. 96-105. Cambridge University Press, Cambridge.

Montañez (1994) Late diagenetic dolomitization of Lower Ordovician, Upper Knox Carbonates: a record of the hydrodynamic evolution of the southern Appalachian Basin. American Association of Petroleum Geologists Bulletin, 78, 1210 -39 .

Montone P, Amato A, Pondrelli S (1999) Active stress map of Italy. Journal of Geophysical Research, 104, 25,595-625, 610.

Mostardini F, Merlini S (1986) Appennino centro-meridionale: sezioni geologiche e proposta di modello strutturale. Memorie della Società Geologica Italiana, 35, 177-202.
Patacca E, Scandone P (2001) Late thrust propagation and sedimentary response in the thrust-belt-foredeep system of the southern Apennines (Pliocene-Pleistocene). In: Anatomy of an Orogen: The Apennines and Adjacent Mediterranean Basins. (eds Vai GB, Martini IP), pp. 40140. Kluwer Academic Publishers, Dordrecht, Netherlands.

Patacca E, Scandone P (2007) Geology of the Southern Apennines. Bollettino della Società Geologica Italiana, Special Issue, 7, 75-119.

Patacca E, Scandone P, Di Luzio E, Cavinato GP, Parotto M (2008) Structural architecture of the central Apennines: interpretation of the CROP 11 seismic profile from the Adriatic coast to the orographic divide. Tectonics, 27, TC3006.

Qing H, Mountjoy EW (1994) Formation of coarsely crystalline, hydrothermal dolomite reservoirs in the Presqu'ile Barrier, Western Canada Sedimentary Basin. American Association of Petroleum Geologists Bulletin, 78, 55-77.

Ronchi P, Di Giulio A, Ceriani A, Scotti P (2010) Contrasting fluid events giving rise to apparently similar diagenetic products; late-stage dolomite cements from the Southern Alps and central Apennines, Italy. Geological Society of London, Special Publications, 329, 397-413.

Rosenbaum J, Sheppard SM (1986) An isotopic study of siderites, dolomites and ankerites at high temperatures. Geochimica et Cosmochimica Acta, 50, 1147-50.

Roure F, Casero P, Vialli R (1991) Growth processes and mélange formation in the southern Apennines accretionary wedge. Earth and Planetary Science Letters, 102, 395-412.

Scandone P (1967) Studi di geologia lucana: La serie calcareosilico-marnosa e i suoi rapporti con l'Appennino calcareo. Bollettino Società dei Naturalisti in Napoli, 76, 1-175.

Scandone P (1972) Studi di geologia lucana: carta dei terreni della serie calcareo-silico-marnosa e note illustrative. Bollettino Società dei Naturalisti in Napoli, 81, 225-300.

Sciamanna S, Sassi W, Rudkiewicz JL, Gambini R, Mosca F (2004) Predicting hydrocarbon generation and expulsion in the Southern Apennines thrust belt by 2-D integrated structural and geochemical modeling: Part I: structural and thermal evolution. In: Deformation, Fluid Flow, and Reservoir Appraisal in Foreland Fold and Thrust Belts (eds Swennen R, Roure F, Granath *JW), pp. 51-67. American Association Petroleum Geologists Hedberg Series 1, Tulsa, Oklahoma, USA.

Scrocca D, Carminati E, Doglioni C (2005) Deep structure of the southern Apennines, Italy: thin-skinned or thick-skinned?. Tectonics, 24, TC3005.

Scrocca D, Sciamanna S, Di Luzio E, Tozzi M, Nicolai C, Gambini R (2007) Structural setting along the CROP-04 deep seismic profile (Southern Apennines - Italy). In: Results of the CROP Project Sub-project CROP-04 Southern Apennines (Italy), (eds Mazzotti A, Patacca E, Scandone P), pp. 283-96. Bollettino della Società Geologica Italiana (Italian Journal of Geoscience), Rome. special issue.

Selleck B, Zangrilli P (2001) Fluid inclusion and stable isotope constraints on temperature and pressure of vein formation, Hudson valley fold-thrust belt, Catskill, N.Y. Northeastern Geology and Environmental Sciences, 23, 1-11.

Shiner P, Beccacini A, Mazzoli S (2004) Thin-skinned versus thick-skinned structural models for Apulian carbonate reservoirs: constraints from the Val D'Agri Fields. Marine and Petroleum Geology, 21, 805-27.

Speranza F, Chiappini M (2002) Thickskinned tectonics in the external Apennines Italy: new evidence from magnetic anomaly analysis. Journal of Geophysical Research, 107, 2290. 
Steckler MS, Piana Agostinetti N, Wilson CK, Roselli P, Seeber L, Amato A, Lerner-Lam A (2008) Crustal structure in the southern Apennines from teleseismic receiver functions. Geology, $36,155-8$.

Suchecki RK, Land LS (1983) Isotopic geochemistry of burialmetamorphosed volcanogenic sediments, great valley sequence, Northern California. Geochimica et Cosmochimica Acta, 47, 1487-99.

Suess E, von Huene R, Leg 112 Shipboard Scientists, Kvenvolden KA (1988) Ocean Drilling Program Leg 112, Peru continental margin, Part 2, Sedimentary history and diagenesis in a coastal upwelling environment. Geology, 16, 939-43.

Taylor TR (1990) The Influence of calcite dissolution on reservoir porosity in Miocene sandstones, Picaroon Field, Offshore Texas Gulf-Coast. Journal of Sedimentary Petrology, 60, 322-34.

Travé A, Labaume P, Vergés J (2007) Fluid systems in foreland fold-and-thrust belts: an overview from the southern Pyrenees. In: Thrust Belts and Foreland Basins from Fold Kinematics to Hydrocarbon Systems (eds Lacombe O, Lavé J, Roure F, Vergés J), pp. 93-116. Frontiers in Earth Sciences, Springer, Chapter 5 , Berlin.

Turco E, Macchiavelli C, Mazzoli S, Schettino A, Pierantoni PP (2012) Kinematic evolution of Alpine Corsica in the framework of Mediterranean mountain belts. Tectonophysics, 579, 193-206.
Veizer J, Ala D, Azmy K, Bruckschen P, Buhl D, Bruhn F, Carden GAF, Diener A, Ebneth S, Godderis Y, Jasper T, Korte C, Pawellek F, Podlaha OG, Strauss H (1999) ${ }^{87} \mathrm{Sr} /{ }^{86} \mathrm{Sr}, \delta^{13} \mathrm{C}$ and $\delta^{18} \mathrm{O}$ evolution of Phanerozoic seawater. Chemical Geology, $161,59-88$.

Vilasi N, Malandain J, Barrier L, Callot JP, Amrouch K, Guilhaumou N, Lacombe O, Muskha K, Roure F, Swennen R (2009) From outcrop and petrographic studies to basin-scale fluid flow modelling: the use of the Albanian natural laboratory for carbonate reservoir characterisation. Tectonophysics, 474, 367-92.

Vrolijk P, Myers G, Moore JC (1988) Warm fluid migration along tectonic mélanges in the Kodiak Accretionary complex, Alaska. Journal of Geophysical research, 93, 10313-24.

Vrolijk P, Fisher A, Gieskes JM (1991) Geochemical and geothermal evidence for fluid migration in the Barbados Accretionary Prism (ODP Leg 100). Geophysical Research Letters, 18, 947-50.

Zachos J, Pagani M, Sloan L, Thomas E, Billups K (2001) Trends, rhythms, and aberrations in global climate $65 \mathrm{Ma}$ to present. Science, 292, 686-93. 


\title{
GEOFLUIDS
}

\author{
Volume 13, Number 2, May 2013 \\ ISSN 1468-8115
}

\section{CONTENTS}

99 EDITORIAL: 2012 Paris Geofluids VII Conference Summary \& Thematic Issue

Rudy Swennen, Francois Roure, Jacques Pironon, Fadi H. Nader and Mark Person

101 Synchrotron XRF and XANES investigation of uranium speciation and element distribution in fluid inclusions from unconformity-related uranium deposits

A. Richard, J. Cauzid, M. Cathelineau, M.-C. Boiron, J. Mercadier and M. Cuney

112 Age and genesis of the White Pine stratiform copper mineralization, northern Michigan, USA, from paleomagnetism

D.T.A. Symons, K. Kawasaki and J.F. Diehl

127 Modelling fault reactivation and fluid flow around a fault restraining step-over structure in the Laverton gold region, Yilgarn Craton, Western Australia

Y. Zhang, P.M. Schaubs, H.A. Sheldon, T. Poulet and A. Karrech

140 Fluid channeling along thrust zones: the Lagonegro case history, southern Apennines, Italy T. Gabellone, M. Gasparrini, A. Iannace, C. Invernizzi, S. Mazzoli and M. D'Antonio

159 Diagenesis versus hydrothermalism and fluid-rock interaction within the Tuscan Nappe of the Monte Amiata $\mathrm{CO}_{2}$-rich geothermal area (Italy)

M. Gasparrini, G. Ruggieri and A. Brogi

180 Diagenetic evolution of a fractured evaporite deposit (Vilobí Gypsum Unit, Miocene, NE Spain) M. Moragas, C. Martínez, V. Baqués, E. Playà, A. Travé, G. Alías and I. Cantarero

194 Geochemical simulations to assess the fluorine origin in Sierra de Gador groundwater (SE Spain) L. Daniele, M. Corbella, A. Vallejos, M. Díaz-Puga and A. Pulido-Bosch

204 Quantification of diagenesis impact on the reservoir properties of the Jurassic Arab $D$ and $C$ members (Offshore, U.A.E.)

F.H. Nader, E. De Boever, M. Gasparrini, M. Liberati, C. Dumont, A. Ceriani, S. Morad, O. Lerat and B. Doligez

221 Dedolomitization and reservoir quality: insights from reactive transport modelling L-.C. Escorcia, E. Gomez-Rivas, L. Daniele and M. Corbella

232 Reflux dolomitization of the Upper Permian Changxing Formation and the Lower Triassic Feixianguan Formation, NE Sichuan Basin, China L. Jiang, C.F. Cai, R.H. Worden, K.-K. Li and L. Xiang

246 Petroleum system evolution in the inverted Lower Saxony Basin, northwest Germany: a $3 D$ basin modeling study

B. Bruns, R. Di Primio, U. Berner and R. Littke 